\title{
Bioelectrochemical and Conventional Bioremediation of Environmental Pollutants
}

John M Pisciotta* and James J Dolceamore Jr

Department of Biology, West Chester University, West Chester PA, USA

\begin{abstract}
Chemical pollutants can adversely affect human and environmental health. In sediments, pollutants such as polycyclic aromatic hydrocarbons (PAHs), heavy metals and pesticides have the potential to exert an array of toxic effects on susceptible organisms. Certain chemicals including dichlorodiphenyltrichloroethane (DDT), various pharmaceuticals and endocrine disrupting agents (ex. nonylphenol) are recalcitrant in sediments, complicating removal. Agents such as dioxins bioaccumulate in plant and animal tissues used for human consumption. Traditional bioremediation employs applied or autochthonous organisms to breakdown or immobilize such environmental contaminants to less hazardous forms. Bacteria, fungi and phototrophs can be used as inexpensive, self-replicating catalysts to metabolize or otherwise neutralize pollutants. Bacteria are particularly useful since metabolically versatile representatives, including various Actinomycetes species, form spores, are resistant to multiple contaminants and survive over a wide range of environmental conditions. Unfortunately, conventional bioremediation suffers from certain drawbacks, like difficulties with subsurface process monitoring. These may be overcome using microbial bioelectrochemical systems (BESs). Recent studies demonstrate that BESs such as sediment Microbial Fuel Cells (sMFCs) can accelerate rates of bioremediation while coupling pollutant metabolism directly to the generation of renewable bio-electricity. BESs can further serve as sensitive pollutant biosensors for remote progress monitoring via existing wireless networks, facilitating bioremediation optimization. Here we review recent progress into conventional and bio-electrochemically mediated bioremediation technologies for common pollutants with a focus on recalcitrant organic pollutants of sediment. Emerging questions, opportunities and drawbacks pertaining to BES microbial technologies are highlighted. Use of BESs to remediate chemically diverse pollutants has proven effective; however, there remains a need to overcome limitations with BES process start up time, scale up and design, remote monitoring and the cost of BES electrodes and catalysts.
\end{abstract}

Keywords: Bioremediation; Bioelectrochemical system; Microbial fuel cell

\section{Introduction}

\section{Overview of pollutant groups}

Industrialization, the global spread of agricultural chemicals, consumer products and expansion of the petrochemical industry to new fields like oil sands and hydraulic fracturing are contributing sources of environmental pollution [1-3]. Pollution of the atmosphere, ground and surface waters contribute potentially hazardous chemicals that have toxic effects on environmental quality and health and can build up in sediments $[4,5]$. The deleterious effects of soil pollutants in particular are far-reaching and numerous. They can cause adverse effects on human and animal health, plant growth and soil fertility [6]. For example, high levels of polycyclic aromatic hydrocarbons (PAHs) in soils are carcinogenic to humans $[7,8]$. Heavy metals can be toxic to plants and animals, causing neurological developmental disruptions in humans [9]. The quantity, diversity, and activity of natural soil microorganisms may also be affected by chemical pollutants [10]. Most pollutants are released as unintended consequences of other activities, most notably transportation. Agriculture is one conspicuous exception in which pollutants are routinely administered to the land expressly because of their known toxicity against target organism populations.

\section{Pesticides}

One of the first widely used, synthetically-produced pesticides was the organochloride class agent DDT. From the Second World War until its ban in the early 1970's, DDT was deployed on a vast scale for control of insects and insect-borne diseases and as a highly effective agricultural pesticide [11]. For example, over a half million pounds of DDT was applied to salt marshes in Cape May County, New Jersey alone between 1946-1966 to kill mosquitoes [12]. DDT demonstrates low solubility, a tendency to partition in the lipophilic phase and contains chlorine atoms that make it and its metabolites, such as DDD and DDE (collectively referred to as DDTr), ecotoxic [13]. Due to this recalcitrance and lipophilicity, biomagnification up the food web into higher level predators, such as fish and certain large birds of prey, has been documented for DDT and another common group of organic pollutants, polychlorinated biphenyls (PCBs) $[14,15]$. In animals DDTr can disrupt the central nervous system, induce oxidative damage in blood cells, and interfere with endogenous hormones [13]. The metabolite DDE inhibits calcium adenosine triphosphatase disrupting eggshell formation in birds [16]. In 1972 DDT was banned in the United States [11]. Chlordane is another persistent organochloride used for termite control and as a herbicide that was banned in 1988 [17]. There has been considerable research to find ways to bioremediate organochloride class pollutants. Several species of bacteria and fungi have the capability to transform DDT into the intermediates DDD and DDE, which are partially chlorinated [13]. However, these intermediates remain difficult to break down due to the presence of chlorine [13]. The organochloride gamma hexachloro-cyclohexane, (lindane) was once broadly used and was banned by most nations in 2009 due to toxic

*Corresponding author: John M Pisciotta, Department of Biology, West Chester University, West Chester PA, USA, Tel: 610-738-0540; E-mail: jpisciotta@wcupa.edu

Received June 06, 2016; Accepted June 29, 2016; Published July 09, 2016

Citation: Pisciotta JM, Dolceamore JJ (2016) Bioelectrochemical and Conventional Bioremediation of Environmental Pollutants. J Microb Biochem Technol 8: 327343. doi: 10.4172/1948-5948.1000306

Copyright: (c) 2016 Pisciotta JM, et al. This is an open-access article distributed under the terms of the Creative Commons Attribution License, which permits unrestricted use, distribution, and reproduction in any medium, provided the original author and source are credited. 
health effects and possible carcinogenicity [18]. As of 2016, some longlived organochlorides, including DDT, remain in use in a number of countries [16].

Current widely used insecticide classes replacing the organochlorides include carbamates (ex. aldicarb), pyrethroids (ex. permethrin) and organophosphates (ex. malathion). Chlorpyrifos (O,O-diethyl O-3,5,6-trichloropyridin-2-yl phosphorothioate) is a widely used broad spectrum organophosphate insecticide that is still in use in the U.S. These newer chemical pesticides tend to break down much more rapidly in the environment than organochlorides like DDT and chlordane. However, even low concentrations of certain pesticides can kill sensitive larval stages of cornerstone species like certain dipterans in aquatic habitats thereby causing ecological disruption [19]. Other agricultural chemicals commonly administered in concert with pesticides can compound their adverse environmental effects.

\section{Herbicides and nutrient pollution}

Agricultural application of herbicides on a grand scale has been underway since the mid-twentieth century [20]. Commonly used herbicides in the United States include $\mathrm{N}$-[phosphonomethyl]glycine (glyphosate, Round Up), 1-Chloro-3-ethylamino-5-isopropylamino2,4,6-triazine (atrazine) and 2,4-Dichlorophenoxyacetic acid (2,4 D) [21]. Application and subsequent run off of nitrogen and phosphorous rich fertilizers from agricultural lands can cause another form of pollution known as nutrient pollution, or eutrophication. The resulting algal blooms and subsequent dies off, settling and decay can result in water column anoxia and large scale ecosystem disruption known as dead zones [22]. Certain genera of algae and cyanobacteria (formerly blue green algae) have the ability to synthesize chemical toxins during blooms. The cyanobacterium Microcystis aeruginosa synthesizes neurotoxins and potent hepatotoxic compounds called microcystins [23]. In 2014 roughly half a million people were directly affected when the city of Toledo's public water supply was shut down due to excessive levels of microcystin likely stemming from excessive nutrient runoff [24]. Interestingly, certain pesticides can up-regulate microcystins. In controlled studies, the organochloride lindane enhanced production of microcystin by M. aeruginosa [25]. The precise mechanism by which this can occur is not yet understood. Some plants have been shown to accumulate cyanobacterial toxins [26]. This suggests ways in which waterways and even entire urban communities located downstream of agricultural production regions may be adversely affected by cocontamination of pesticides plus nutrient run-off [25]. Aside from large agricultural producers, individual homes and businesses also contribute to herbicide pollution run-off associated with lawn care, particularly in highly populated regions with extensive paving or other forms of impervious ground cover.

No herbicide is completely specific towards a targeted weed or plant species. Many herbicides also detrimentally affect sensitive animal species, such as the agriculturally essential honey bee Apis melifera [27]. Even in sub-PPM (parts per million) concentrations, glyphosate (Round Up) has been shown to result in $80 \%$ mortality of frog tadpoles in laboratory tests [28]. The herbicide Agent Orange consists of butyl 2-[2,4-dichlorophenoxy]acetate combined with butyl2[2,4,5-trichlorophenoxy]acetate and was widely used as a defoliant in southeast Asia during the Vietnam conflict. Dioxins are carcinogens that are known to have contaminated this herbicide that can transfer from the soil into food crops up the food chain to humans [29,30]. Like organochlorides, dioxins are highly recalcitrant but they can be far more toxic to humans [31]. Herbicides can compound the lethal effects of trace levels of pesticides in a synergistic manner by up to 9-fold [32].
This raises important concerns particularly for streams and tributaries downstream of fields that are treated with herbicides and pesticides, as is often the case with widespread corn and soy agriculture.

\section{Polycyclic aromatic hydrocarbon (PAH) contamination}

PAHs represent a range of organic molecules formed as a result of incomplete combustion [33]. The EPA has designated 32 PAH compounds as priority pollutants [34]. PAHs formed at high temperatures generally are most readily degraded [35]. PAHs formed at lower temperatures tend to have more rings, lower water solubility and are more recalcitrant [35]. While the majority of PAHs enter the environment via the atmosphere, soil and sediments represent the primary environmental sites of accumulation [34]. It is estimated that automobiles are responsible for approximately $35 \%$ of all $\mathrm{PAH}$ emissions in densely populated cities in the United States [34]. In humans, PAHs exhibit carcinogenic and mutagenic effects while PAHs in the environment are stable and recalcitrant in soils [36]. As a result, these compounds are difficult to remove using conventional methods. Petroleum hydrocarbons are additional pollutants associated with transportation that can be released from pipeline and tanker spills and related sources that can adversely affect waterways [37].

\section{Pharmacological agents}

Pharmaceuticals and drug-like chemicals can be shed to the environment from various point sources including hospitals, wastewater treatment plant outfalls and landfills. Drug-like chemicals, such as bisphenol $\mathrm{A}$, can be leached from plastics into aquatic environments where they cause ecological disruption of fish populations by disrupting normal hormonal functioning and sexual development [38]. Certain drugs, like fluoroquinolone and tetracycline antibiotics as well as endocrine disruptors are long-lived in the environment, bind to and accumulate in sediments $[39,40]$. Release of antibiotics from point sources may promote the spread of antibiotic resistance genes in naturally present bacterial populations [41]. Many antibiotics consumed in the U.S. are administered to promote healthy animal growth. Agricultural sites like cattle farms and swine waste lagoons, as well as wastewater plants, are associated with significantly elevated levels of antibiotic resistant bacteria [42]. Today, treated wastewater is increasingly being used to provide water for agricultural and landscaping operations in many parts of the world. Pharmaceuticals in reclaimed water can accumulate in soil and sediment through a process of evaporative enrichment [43]. The long term implications of this form of pollution have not been determined.

New classes of pollutants are beginning to affect human health and environmental quality in ways not yet fully understood. Novel classes of pollutants include engineered nanoparticles. These are becoming widely used in many consumer products, such as sunscreens. Nanoparticles have been shown to alter soil microbial populations and reduce photosynthetic rates in plants [44,45]. Multiple different pollutants frequently co-contaminate field sites, complicating cleanup. The ways in which overlapping pollutants affect one another and organisms is not known. Residual pollutants may hasten breakdown of other chemicals. For example, $\mathrm{TiO}_{2}$ nanoparticles accelerate breakdown of fluoroquinolone antibiotics [46]. Preferably, biologicallybased, rather than chemically-based methods should be used. Ideally, native species may be selectively employed so genetically modified or allochthonous (i.e., non-native) species can be avoided, minimizing potential environmental perturbation.

\section{Conventional bioremediation}

Mycoremediation: Mycoremediation is a form of bioremediation 
that employs fungi to address environmental contamination. Fungi primarily use three processes to decontaminate environments: 1) biodegradation, 2) biosorption and/or 3) bioconversion [47]. During biodegradation, fungi secrete extracellular enzymes that progressively oxidize organic pollutants resulting in partial or complete catabolism with mineralization to inorganic molecules. Classes of secreted enzymes involved in fungal pollutant biodegradation include extracellular peroxidases, peroxidases, cellulases, pectinases, xylanases and oxidases $[48,49]$. Biosorption refers to toxin binding and immobilization. Aside from surface binding, some fungi, known as Vesicular Arbuscular Mycorrhiza (VAM) can also transport contaminants into intracellular compartments [47]. Environmental conditions such as soil pH can influence affinity of biosorption to some chemicals. Efficient fungal biosorption of the pollutant pentachlorophenol (PCP) was possible only at pHs below 6.0 as it is likely mediated by non-covalent interactions between the pollutant and amides, alkanes, carboxylates, carboxyl and hydroxyl groups of fungal mycelia [50].

Fungi with ligninolytic ability often have the ability to break down a range of environmental pollutants, including DDT. In 1987, Bumpus and Aust [51] were among the first to present evidence that the white rot fungi Phanerochaete chrysosporium, which have the uncommon capacity to break down lignin, can also mineralize DDT. It is proposed that the lignin-degrading system of the fungus plays a major role in the breakdown of DDT and its intermediates [11]. Enzymes used in the degradation of lignin are lignin peroxidase (LiP), manganesedependent peroxidase $(\mathrm{MnP})$, manganese-independent peroxidase (MIP) and laccase [11]. Lignin peroxidases are distinct in that they have higher oxidation potentials than most peroxidases [52]. Over the course of thirty days, P. chrysosporium lacking nitrogen converted $50 \%$ of DDT with approximately $10 \%$ mineralized and the remainder as oxidized metabolites [51]. This group proposed that DDT is degraded by way of oxidation to become dicofol. A product of this initial phase was DDD, which was then degraded during the initial non-ligninolytic stage. They concluded that DDD was produced exclusive from the ligninase system. Dicofol became dechlorinated and was converted to DBP and then mineralized to $\mathrm{CO}_{2}$. Bumpus and Aust [51] showed that this system is controlled by ligninase by observing that mineralization and ligninase production only occurred after a lag phase.

(ex. Pleurotus ostreatus) are enzymatically versatile fungi capable of remediating various chemicals, including DDT. These common edible mushrooms were initially developed in the West by Flack as a food item toward the end of World War 1 as a result of food shortages [53]. For every kilogram of mushrooms produced, nearly $5 \mathrm{~kg}$ of spent mushroom waste (SMW) is produced. Purnomo et al. [11] examined whether nutrients and enzymes present in this SMW could be used for low cost bioremediation with additional environmental benefits. It was found that DDT was degraded $48 \%$ over a 28 day period by $P$. ostreatus by the ligninolytic enzymes MnP, LiP and laccase. Purnomo et al. [11] suggested that soil bacteria also play a role in the transformation of DDT to DDD by reductive dechlorination as SMW degraded DDT by approximately $80 \%$ in unsterilized soils yet only $40 \%$ in sterilized soils, highlighting the interaction between fungal eukaryotic and bacterial populations. Soil microbial populations may increase due to the nutrients (ex. nitrogen, phosphorous) present and released from SMW.

Other organic pollutants can be mycoremediated using filamentous fungi or yeasts which have the capability to degrade PAHs through oxidative transformation. Intracellular cytochrome P450, extracellular $\mathrm{LiP}, \mathrm{MnP}$, and laccase are enzymes that are utilized for this by different species of fungi [54]. P. chrysosporium is able to break down PAHs found in anthracene oil, which forms as a result of the distillation of coal tar [55]. Phenanthrene, a primary component of the oil, was oxidized to $\mathrm{CO}_{2}$ by the lignin-degradation system of $P$. chrysosporium [55]. Pleurotus pulmonarius SMW is able to biodegrade PAHs [56].

Recalcitrant drugs and drug-like molecules and endocrine disrupting pollutants that accumulate in soil can be effectively removed through mycoremediation. P. ostreatus oyster mushrooms efficiently and almost completely degraded oxytetracycline in two weeks in controlled lab studies [57]. The antimicrobial activity of medically-important fluoroquinolone class antibiotics was obviated by Irpex lacteus white rot fungi, probably through enzymatic cleavage of the drug's piperazine ring [58]. Certain fungi, including both aquatic species and oyster mushrooms, can degrade the common organic endocrine disruptor bisphenol A $[59,60]$. The biodegradation of endocrine disrupting compounds, including bisphenol A, is mediated by fungal laccases and can be enhanced though enzyme immobilization onto glass beads in the presence of chemical mediators [61]. Many agricultural and vegetable wastes can easily be converted into oyster mushrooms [62]. The ability of the oyster mushroom to take up iron has led to it being considered as an alternative to produce non-animal food sources of iron [63]. However, since $P$. ostreatus is capable of bio-accumulating certain toxic metals like mercury up to 140 times; mushrooms should not be consumed if used for bioremediation through growth on substrate wastes contaminated with heavy metals. Toxic metals can be removed through biosorption using SMW of Lentinus edodes or oyster mushrooms $[64,65]$.

Phytoremediaton: Phytoremediation is a promising form of bioremediation that uses naturally occurring, or genetically modified plants, often in symbiosis with soil microorganisms, to facilitate toxin decontamination and/or reuptake from soil and water [66]. Phytoremediation is useful for the treatment of both organic and inorganic compounds in the environment. Organic contaminants, such as atrazine, DDT, PAHs, and PCBs can be degraded in the root zone of a plant, or taken up and then degraded, sequestered, and volatized into the air [67]. Inorganic contaminants, such as iron and copper, however, are unable to be degraded; instead, they are stabilized or sequestered in the tissue of the plant [67]. DDT can be removed from soil through phytoremediation and may be facilitated by arbuscular mycorrhizal (AM) fungus in the root zone [68]. The greater the hydrophobicity of an organochloride, the more likely it is to accumulate in the plant tissue [69]. Phytoremediation is an attractive alternative for pollutants near the soil surface and within the root zone for it can be applied to large areas at low cost by utilizing standard planting methods and can make use of fast-growing energy crops.

In PAH contaminated soils, there are four mechanisms at work during phytoremediation: 1) direct absorption of PAHs by the plant, 2) plant volatility and adsorption, 3) secretion of plant enzymes to decompose $\mathrm{PAH}$, and 4) breakdown in the rhizosphere [70]. Enzymes released by the roots into the soil, such as soybean peroxidase, have been shown to break down PAHs such as anthracene through oxidation [71]. Liu et al. [70] studied the Fire Phoenix plant's ability to bioremediate PAH contaminated soils and discovered that the Fire Phoenix (Festuca arundinacea) stimulates the conversion of phenol compounds in the rhizosphere into quinone compounds using oxidoreductase to form humic acid molecules. In particular, an increase in the activity of the following enzymes correlated with an increase in PAH degradation rates: 1) polyphenol oxidase, an oxidoreductase involved directly in the conversion of aromatic organic compounds to humic segments; 2) dehydrogenase, which is a strong indicator of diverse microbial activity and a possible role in PAH degradation; 3) peroxidase, which is initiated by PAH stresses to assist lignin biosynthesis and other stresses [70]. In 
addition, the Fire Phoenix promoted the growth of the Gordonia sp. of bacteria, which can degrade PAHs.

While phytoremediation is a promising method of bioremediation, certain limitations exist. The plants that have a role in contaminant removal must be able to grow and survive where the pollutant is found, therefore, the toxicity, soil and climate must be conducive for plant growth [67]. Root depth is another issue; the root depth must be deep enough in order to reach the polluted soil [67]. The time needed to grow the plants for phytoremediation and the time required to decrease contaminant levels can take years or even decades [66]. Although many larger plants cannot be grown on flowing water bodies, plant bark has been successfully used as a biofiltration material for the removal of heavy metal from water [72].

Phycoremediation is a related technique that employs algae or beneficial cyanobacteria to overcome some of the above limitations, like slow plant growth rate and the inability of most plants to grow on the surface of water bodies, like polluted lakes. Not only can diverse microbial phototrophs grow rapidly and bioaccumulate certain toxins, like heavy metals, subsequent harvesting can facilitate the recovery of valuable metals [73]. Metals can be removed from polluted waters via the process of surface biosorption and/or intracellular accumulation [74]. Recovery of valuable metals could serve as one economic driver for this form of bioremediation. Lipid-rich algae grow most rapidly on illuminated, eutrophic waters, and so can be used to remove nitrogen and phosphorous nutrient pollutants [75]. Lipid-rich microalgae can grow on contaminated tannery wastewaters and may be converted to biodiesel or other forms of renewable biofuel [76]. Coupling bioenergy production to environmental phycoremediation or phytoremediation is a promising strategy for reducing humanity's dependence on petroleum while concurrently removing pollutants to protect downstream waterways. Phototrophs can support BESs [77-80]. Some microbial phototrophs, like the cyanobacterium Anabaena PD-1, directly decompose recalcitrant, dioxin-like PCBs [81]. The organochloride lindane can also be catabolized [82].

Bacterial bioremediation: Bacterial bioremediation seeks to break down environmental contaminants using aerobic and/ or anaerobic bacteria. Techniques include: biostimulation through selective enrichment of autochthonous soil bacteria populations; bioaugmentation through addition of specific bacterial strains; bioaccumulation with storage of contaminants inside live cells; biofilm biosorption, which involves removal of contaminants through surface adsorption [83]. An advantage of bacterial bioremediation is that bacteria are often resistant to the presence of specific contaminants. Bacteria utilize their surroundings and interaction with organisms to obtain carbon, energy and nutrients needed for growth [83]. Consequently, the availability of carbon, energy and or nutrients can be a limiting factor for microbial growth, reducing the rates of pollutant degradation [84]. In accordance with Liebig's Law of the Minimum, the major limiting factor isn't the sum of the total resources available, but rather the scarcest nutrient available relative to the microbial species' demands. Identifying and delivering the limiting resource[s] can thus optimize bioremediation [85]. Ideally, the pollutant being catabolized may serve as a source of both energy and carbon in the case of heterotrophic species. Autotrophic bacteria, such as cyanobacteria, can be useful for bioremediation of pollutants that lack organic carbon, like certain metals [86]. Chemolithoautotrophic bacteria such as Thiobacillus sp. have the ability to bioremediate heavy metals in soil or sediment by producing metal-leaching sulfuric acid [87]. These metals can then be removed as insoluble sulfides using sulfate-reducing bacteria [87]. One advantage of lithoautotrophs is that organic carbon is not required. Use of diazotrophic autotrophs can reduce the demand for added nitrogen. Regulation of the relative ratios of macronutrients can help optimize biodegradation. In a recent study, petroleum hydrocarbons were most rapidly biodegraded when the C:N:P ratio of was 100:15:1 [10]. Bioremediation using genetically modified organisms (GMOs) has shown promise but the ecological effects and broader implications of releasing genetically modified microbes are the subject of considerable debate $[88,89]$.

Bacterial transformation of DDT proceeds under reducing conditions via a reductive dechlorination and is a major pathway to form DDD. According to Holliger et al. [90], reductive dechlorination reactions use anaerobic bacteria for catalysis using co-metabolic activity, which is commonly associated with alkyl halides. This reaction is driven by the substitution of an aliphatic chlorine atom for a hydrogen atom [91]. This activity is non-specific and associated with facultative and obligate anaerobic bacteria. Reductive dechlorination requires an electron transfer, removal of a chlorine ion, and the formation of an alkyl radical [91]. Mendel et al. [92] were among the first in 1966 to show coliform bacteria from gastrointestinal tract of rats were able to breakdown DDT to DDD by reductive dechlorination. Diverse bacteria have subsequently been found to be capable of reductive dechlorination of DDT $[91,84]$. Other species utilize oxidative catabolism. Nadeau et al. [93] studied the ability of Alcaligenes eutrophus A5 (Ralstonia metallidurans) to break down DDT. The first step is the oxidation on the phenyl ring at adjacent ortho and meta positions, which lead to formation of a two hydroxyl-DDT intermediate 2,3-dihydrodiol-DDT [93]. Like white rot fungi, some Rhodococcus species have the uncommon ability to break down lignin using peroxidases [94]. Rhodococcus sp. strain Lin-2 is able to catabolize DDT [95]. Stenotrophomonas sp. DDT-1 has recently been found to completely mineralize DDT to $\mathrm{CO}_{2}$ under aerobic conditions [96]. Li et al. [97] showed that Shewanella decolorationis S12 reduces DDT to DDD under anaerobic conditions via reductive dechlorination. This can be hastened by the addition of $\alpha-\mathrm{FeOOH}$, where biogenic Fe [II] acted as a mediator for the transformation of DDT [97]. Related Shewanella putrefaciens reductively dechlorinates DDT by a similar mechanism [98] Shewanella genus includes known exo-electrogenic species, including $S$. putrefaciens, that can be cultivated in BESs [99]. It is plausible DDT breakdown could be accelerated by cultivating Shewanella sp. in BESs implanted in contaminated soils.

Certain organic pollutants can serve as both carbon and energy source for microbes capable of catabolizing them. Trichloroethene (TCE) is a common ground water pollutant that can be completely broken down by aerobic bacteria that are able to use TCE as their sole growth substrate [100]. Bacteria such as Pseudomonas fluorescens and Kocuria sp. are able to break down PAHs as a carbon and energy source reducing the toxicity of PAHs [101,102]. The rate and degree of PAH breakdown is based on the number of rings. High molecular weight (HMW) PAHs are generally more resistant to breakdown [101] Degradation initiates with the oxidation and meta-cleavage of $\mathrm{PAH}$ to a catechol, which is then hydrolyzed to TCA cycle intermediates for complete mineralization via central metabolism [101]. Bacteria integrate two oxygen molecules into a benzene ring through a dioxygenase to form a cis-dihydrodiol, which is converted to a catechol. Once the first ring is degraded, the second ring is broken down in the same fashion [101]. In crude oil-contaminated soils, bacteria inculding Pseudomonas aeruginosa B7, Klebsiella sp. B10, and Stenotrophomonas maltophilia B14 along with the fungal species Trichoderma asperellum H15, Aspergillus nomius $\mathrm{H} 7$ and Aspergillus flavus $\mathrm{H} 6$ have been examined as a consortium [103]. This consortium showed an ability to grow using various PAHs including phenantrene, pyrene and 
benzo[a]pyrene as the carbon source. The consortium was tolerant to concentrations up to $6,000 \mathrm{mg} / \mathrm{L}$, and was able to degrade high molecular weight PAHs [103].

\section{Drawbacks of conventional bioremediation}

Unlike strictly chemical or physical remediation methods, one drawback of natural bioremediation is that the environmental and nutritional conditions must be conducive to the survival of the organism(s) being used. Microorganisms may be susceptible to seasonal variations at field sites. Growth and metabolism is typically reduced or halted at low temperatures which may predominate in winter for many of the mesophilic strains developed in laboratory conditions. Low moisture related xeric stress can prove problematic for bioremediation in contaminated desert sites. Conversely, areas prone to flooding could see inoculated microbial counts reduced or eliminated as cells or spores are washed downstream.

While PAHs can meet energy and carbon needs other macronutrients can limit biodegradation. The C/N/P ratio of 100/10/1 appears to enable the most rapid PAH catabolism [104,105]. Microbes also can take considerable time to increase in population size. Fertilization of polluted, oligotrophic environments is costly and not always practicable or advisable. In such situations the use of nitrogen fixing cells could be advantageous. The diazotrophic bacterium Polaromonas naphthalenivorans strain CJ2 has been shown to degrade coal tar via a pathway that interestingly appears to involve nitrogenase [106]. Environments polluted with hydrocarbons, or other chemicals, may also be inaccessible or inhospitable to mesophilic organisms commonly used for bioremediation. However, the Deepwater Horizon offshore disaster of 2010 revealed that even in extreme conditions, autochthonous microbes can often expand to rapidly remediate even large spills [107]. A major drawback of conventional bioremediation is that it is often difficult to monitor the progress of bioremediation and viability of microbes in field sites, particularly below the soil surface. This is exacerbated in remote field site locations where regular sampling may not be practicable.

\section{Bioelectrochemically Active Microbes}

\section{Exo-electrogens}

Microorganisms with the capacity for extracellular electron transport are referred to as exo-electrogens. These organisms evolved in anaerobic environments to use metal oxides as terminal electron acceptors to enable catabolism of organic compounds. Organic compounds catabolized by electrode populations can include known pollutants. Most electron acceptors used by bacteria are freely soluble, however, Fe (III) and Mn (IV) are oxyhydroxide minerals that are poorly soluble [108]. Under anoxic conditions, metal-reducing bacteria can use the cellular electron transport system (ETS) with insoluble minerals or conductive surfaces such as graphite electrodes as their terminal electron acceptor [108].

Exo-electrogenic communities enriched on graphite anodes show considerable diversity and include both Gram-positive and Gramnegative bacteria. Gram-negative bacteria are most important for current production, although some Gram-positive bacteria have shown a limited capacity for external electron transfer [109]. Physiologically, exo-electrogens utilize three known mechanisms for electron transfer to the anode: 1) direct contact using outer membrane cytochromes, 2) excreted chemical redox mediators or electron shuttles and/or 3) conductive appendages that transfer electrical current referred to as microbial nanowires [110-113]. Improved understanding into the physiological mechanisms used by electrode populations should improve renewable electric current generation from the catabolic break-down of organic wastes, such as organic pollutants. The two most rigorously investigated genera of exo-electrogens to date are Geobacter and Shewanella.

\section{Geobacter sulfur reducens and Geobacter metallireducens}

Geobacter is a widely studied gram-negative genus of metalreducing bacteria. Geobacter sulfurreducens is a rod-shaped, nonmotile, anaerobic bacteria commonly found below the surface in soils and aquatic sediment [114]. G. sulfurreducens catabolizes acetate to carbon dioxide and water through oxidation; and is capable of reducing sulfur [for which it is named], fumarate and iron oxides [114]. Geobacter metallireducens is a closely related species found in soils and aquatic sediments [115]. G. metallireducens is a reducer of iron, manganese, uranium, and many other metals. G. metallireducens has also been shown to oxidize organic compounds to carbon dioxide with iron oxides as the electron acceptor; as well as oxidize short chain fatty acids, alcohols, and monoaromatic compounds with iron as the electron acceptor [115].

Geobacter species use direct contact in order to reduce Fe (III) oxides and manufacture monolateral pili [110]. These nanowires allow electron transfer outside the outer surface of the cells which is key in soils where Fe (III) oxides are heterogeneous coatings on clays [110]. Nanowires are attached at the periplasm and outer-membrane of Gram-negative cells that allow the acceptance of electrons from the periplasm or outer-membrane electron transfer proteins. Nanowires serve the function of completion of the circuit between electron carriers and the Fe (III) oxide. In addition to the electron transfer to Fe (III) oxides, nanowires appear to also play a role in electron transfer from cell-to-cell [110].

\section{Shewanella oneidensis}

The Shewanella genus is a gram-negative, rod shaped, facultativeaerobic bacteria found in deep-sea anaerobic environments as well as soil and sediment [116]. Shewanella are considered to have the greatest diversity of respiration techniques including direct electron transfer using c-type cytochromes (OMCs), indirect electron transfer using flavins and nanowires [117]. Shewanella oneidensis has the ability to reduce heavy metals and is highly resistant to heavy metal poisoning.

The electron-shuttle model suggests that the microbe itself has the ability to produce and utilize soluble mediators such as phenazine and quinones that remove the need for direct contact between cell and electron acceptor [118]. Shewanella BrY has been shown to secrete extracellular melanin. Melanin acts as an electrical conduit to Fe (III) minerals and leads to an increased rate of reduction of $\mathrm{Fe}$ (III) [119]. The melanin produced serves a role as a soluble Fe (III) reductant, electron conduit for $\mathrm{Fe}$ (III) reduction, and as a terminal electron acceptor [119]. S. oneidensis MR-1 has been shown to secrete flavins, in particular riboflavin-5'-phosphate and riboflavin as electron shuttles [120]. The selection of an electron acceptor, such as fumarate and trimethylamine oxide (TMAO), likely plays a major role in affecting the secretion of flavins and influences microbial extracellular electron transfer [120].

Both Shewanella and Geobacter are capable of electron transfer to anodes using a chain of c-type cytochromes that exist along the cellular envelope to electron acceptors found extracellularly [121]. In direct electron transfer, the reduction of Fe (III) occurs outside the cell with a protein found in the outer membrane, usually, a terminal iron reductase [122]. Electrons are transferred from a dehydrogenase to a quinone that 
consists of ubiquinones and menaquinones that are localized in the cytoplasmic membrane to c-type cytochromes and then to a terminal reductase in the outer membrane [122]. Between the two genera, the terminal reductases differ; Shewanella oneidensis utilizes OmcA and $\mathrm{MtrC}$, while Geobacter sulfurreducens utilizes OmcE and OmcS that are capable of direct transfer of electrons to extracellular acceptors, or donation of electrons to extracellular redox compounds, such as humic compounds or riboflavins [122].

\section{Electrotrophs}

Traditionally, researchers have focused on anode associated populations of exo-electrogens and have little investigated cathode populations. Largely this was because only anode populations tend to develop as thick, colorful biofilms. More recently, however, it has become evident that cathode-associated populations can facilitate electron exchange from BES cathodes [123]. Since these organisms are involved in uptake of electrons from BESs for growth and metabolism, certain cathode-associated microbes are referred to as electrotrophs [124,125]. Compared to anode exo-electrogens, the physiological mechanisms electrotrophs use for electron transfer are poorly understood [126]. An improved understanding of the microbial populations associated with both bio-anodes and bio-cathodes could facilitate renewable energy generation and BES-based bioremediation. There are a number of types of devices that can be used to cultivate such electrode populations in controlled laboratory as well as actual field sites. Deeper understanding as to how microbial electrode populations differ between field sites is an important research area.

\section{Bioelectrochemical systems (BESs)}

Bioelectrochemical systems (BESs) can facilitate bioremediation and the generation of energy and/or chemical products. Various types of BES have been developed including Microbial Fuel Cells (MFCs), Microbial Electrolysis Cells, (MECs) and Microbial Desalinization Cells (MDCs). BESs possess two electrically connected electrodes, an anode and a cathode. In BESs, microbes on one or near the anode, facilitate waste (i.e. fuel) breakdown in MFCs. Exo-electrogens grow on the anode electrodes as a biofilm and are crucial in the generation of current, contaminant degradation, and/or biosynthesis in a BES [117]. BESs utilize exo-electrogens that are attached to one and/or both bioelectrodes in order to a) catalyze an oxidation reaction on the bioanode and/or b) catalyze a reduction reaction on the biocathode [127]. A microbial fuel cell (MFC) is a BES where electrical power is generated, whereas a microbial electrolysis cell (MEC) uses electricity to initiate a reaction [127]. Cathode-associate microbes may also be involved in electricity generation and/or bioremediation, particularly in the case of mineralization, immobilization and or reductive decontamination $[128,129]$.

The addition of a BES enhances bioremediation of organic solvents because bioanode bacteria catalyze the oxidation of organic electron donors to the anode [130]. An organic contaminant, such as petroleum hydrocarbons gives a readily available source of terminal electron acceptors to a soil environment that is thermodynamically lacking in electron acceptors (i.e., oxygen) otherwise [131]. This process leads to the stimulation of contaminant removal and does not require the addition of chemical energy; hence, the cost to degrade the contaminants is lower compared to other methods of bioremediation such as chemically catalyzed anodes (such as platinum) [132,133]. This is due to the fact that a chemical anode generates electrons at a low potential (high energy level), whereas the anode electrons are produced at relatively high potential if low energy level [32]. BESs are useful in their ability to generate electrical power or products in remote locations with lower levels of greenhouse gas emissions in comparison to traditional technologies [133]. In addition, BESs may utilize the power generated for self-monitoring purposes.

\section{Microbial fuel cell}

In a microbial fuel cell (MFC), bacteria oxidize reduced organic substrates and release electrons produced to the anode, where they travel through an external circuit to the cathode and create a current (Figure 1) [134]. Per each electron produced, a proton travels into the cathode to maintain a current. The electrons and protons form a reaction with oxygen in the cathode with a mediator to form water. There is often a proton exchange membrane (PEM) between the anode and cathode that allows for the passage of protons from the anode into the cathode. The membrane also serves to separate oxygen from the bacteria, which allows for a charge transfer between electrodes (Figure 1). In the case of bioremediation, a MFC can be used to power a system that drives reactions to breakdown organic chemicals. In such systems, bacteria can donate electrons to the electrode and accept electrons from the cathode $[125,134]$.

MFCs can use a chemical mediator or they can be mediator-less. A mediator-based MFC utilizes chemical mediators such as neutral red or anthraquinone-2,6-disulfonate (AQDS), which are added to allow the production of electricity by bacteria that wouldn't be able to utilize the electrode otherwise [134]. A disadvantage to using a mediator is that they are often costly and toxic. AQDS commonly is lost during the first-time usage. Mediator-less MFCs do not require the addition of an outside mediator to the system; rather, these cells utilize cytochromes and/or nanowires to transfer electrons from the cell directly to the electrode $[108,134]$.

\section{Microbial electrolysis cell (MEC)}

A microbial electrolysis cell (MEC) is a type of BES that, unlike an MFC, requires input of electrical energy. MFCs use the applied energy to enable otherwise non-spontaneous electrochemical or bioelectrochemically catalyzed reactions that result in production of hydrogen. At the anode of an MEC, oxidation of organic compounds is carried out by exo-electrogenic bacteria with deposition of the organically-derived electrons into the BES circuit. This is identical to an MFC and results in initial establishment of a voltage difference between anode and cathode with the generation of electrical current. As electrons flow from the anode to the cathode the voltage is boosted using an external power supply. Voltage could be boosted using a photovoltaic panel or other renewable power converter. Another important difference between an MFC is that the MEC has an anaerobic cathode [135]. The added voltage and lack of oxygen allows protons to be reduced and hydrogen gas forms at the cathode [136]. The addition of an applied voltage is necessary because the formation of hydrogen gas using an organic molecule such as acetate is non-spontaneous during normal conditions [135].

Membranes are often added to MECs for increased hydrogen concentrations and to prevent scavenging of hydrogen by bacteria at the anode. Call and Logan [135], however, showed that high hydrogen recovery rates were possible without the use of a membrane. One undesired byproduct of the membrane-less MEC is the production of methane due to hydrogenotrophic methanogens which use $\mathrm{H}_{2}$ as electron donor and $\mathrm{CO}_{2}$ as the terminal electron acceptor. Clauwaert and Verstraete [136] showed that the production of methane in membrane-less MECs is difficult to avoid due to the presence of biofilms that favor methanogens and protect them from high oxygen 
concentrations and washout. Two major groups of methanogens exist, the acetoclastic methanogens and the hydrogenotrophic methanogens which can use cathodic hydrogen as their electron source. One innovative way to target the highly $\mathrm{O}_{2}$ sensitive populations is the use of electrode polarity inversions. By periodically converting the MEC cathode to an electrolytic anode by polarity inversion, $\mathrm{O}_{2}$ generated on the electrode inhibited methanogens resulting in elevated hydrogen production [137].

\section{Sediment microbial fuel cell (sMFC)}

Sediment microbial fuel cells (sMFCs) use the same principals as MFCs; however, the system uses sediment as the anodic media, inoculum, and PEM. Sediment is naturally composed of a diverse community of bacteria, including exo-electrogens that are required to fuel MFCs, as well as sugars and nutrients that have amassed over millions of years of decay [138]. In addition, aerobic bacteria found at the top of the sediment serve as a natural oxygen filter similar to the filter found in a standard MFC. This allows the redox potential of the sediment to decrease with increased depth. At extreme depths, the cathode receives enough oxygen through the continuous circulation of water [138]. Sequencing analysis has shown that Geobacter, many strains of which has a preference for freshwater, is the principal genus found on the anode of a freshwater sMFC [139]. A major application of sMFCs is the use of the fuel cell to generate electricity in aquatic sediments to power electronic devices, like sensors, that are found in remote locations that would normally be costly to replace batteries [139]. Tender et al. [140] were able to show that a sMFC was capable of powering a meteorological buoy that measures air temperature, pressure, relative humidity, and water temperature. Powering the buoy with a sMFC can allow for an unlimited and maintenance-free power source. A pilot study recently demonstrated that sMFCs could also be integrated into constructed wetlands possibly offering a look into of how civil and environmental engineers may integrate BESs into construction projects in the future [141].

\section{Sediment microbial electrolysis cell (sMEC)}

Sediment Microbial Electrolysis Cells (sMECs) differ from sMECs in that energy must be put into the system. Microbes from sMFCs can be used to seed electrode populations to MECs [125]. Purely electrochemically driven electrolysis in normally anaerobic zones of polluted marine sediments has been shown to accelerate petroleum bioremediation up to $300 \%$ [142]. This is likely attributable to the high catabolic rates of aerobic microbes that can be supported using electrolytically generated oxygen from the anode. Little research into sMECs has as of yet been conducted, but sMECs could conceivably play a role in BES-based bioremediation in certain types of polluted and flooded sediments in both marine and freshwater environments.

\section{MFC power density and coulombic efficiency}

Power density is the measure of power per a specific volume (e.g. $\left.\mathrm{mW} / \mathrm{m}^{3}\right)$. In order for MFCs to be used as sensors, reductions in size and high levels of current and power must be sustained in order to fulfill the power requirements for the system. The decrease in MFC size may lead to a decrease in current and power due to a decrease in the surface area of the electrode surface and cross-sectional area of the PEM [143]. In order to maintain power density, the surface-area-to-chamber volume ratio of the electrode must be increased, while also conserving a short length of diffusion across the smaller sensor. Ringeisen et al. [143] used this principal to design a MFC with a Shewanella oneidensis DSP10 pure culture that produced a maximum power density of 24 and 10 $\mathrm{mW} / \mathrm{m}^{2}$ using reticulated vitreous carbon and graphite felt electrodes, respectively, without the use of exogenous mediators. The power density increased 30-100\% when electron mediators were added [143].

One major limiting factor of power density and coulombic efficiency in the MFC is the supply of organic substrate, which serves as a source of carbon and energy for the exo-electrogens [144]. The substrate has an effect on the bacterial composition on the anode as well as the power density and coulombic efficiency. Coulombic efficiency is the amount of coulombs in the formation of electrical current relative to the maximum attainable if there is complete oxidation of substrate [145]. Chae et al. showed that acetate as a substrate had the highest coulombic efficiency $(72.3 \%)$, above butyrate $(43.0 \%)$, propionate (36.0\%), and then glucose (15.0\%). Glucose as the substrate had the lowest coulombic efficiency due to fermentation, which occurred because supply was being exhausted by competition from non-exoelectrogenic bacteria [146]. The glucose substrate containing MFC had the greatest amount of bacterial diversity, which allowed for current generation without a lag during start up and substrate consumption with the highest power densities [146].

Cathode performance is another factor that affects power density of the system due to the modest kinetics of the reduction of oxygen. Reduction of the internal resistance of the reactor or catalyst alternatives, such as carbon cathodes with platinum or graphite electrodes that utilize iron are ways to increase cathode performance of platinum catalysts at room temperature [147]. Oh et al. [148] compared ferricyanide to dissolved oxygen as electron acceptors in the cathode and increased power density by $50-80 \%$ compared to dissolved oxygen. This occurred due to increases in the efficiency of mass transfer and there was an increase in cathode potential with ferricyanide compared to dissolved oxygen [148]. A disadvantage of ferricyanide is that once it is reduced, it must be replaced, whereas atmospherically-delivered or photosynthetically produced oxygen is essentially limitless as an electron acceptor [125,148]. Cheng et al. [147] showed that the addition of platinum as a catalyst provided 4-times greater power density than a standard carbon cathode. Interestingly, decreasing the amount of platinum 5-fold had minimal reduction in the power density of the system [147].

BES membrane configuration can influence performance. In a two-chamber MFC there is an anode and cathode separated by a PEM (Figure 1). This facilitates oxygen delivery to only the cathode. Liu and Logan [149] compared the power density of a single-chamber MFC using carbon electrodes with and without a PEM. When the PEM was removed, there was a higher power density due to an increase in the potential of the cathode [149]. However, the coulombic efficiency was lower for the MFC without a PEM. This was possibly due to the loss of substrate that occurred from aerobic oxidation by anodic bacteria [149]. Due to the high cost and fragile nature of PEM membranes it is anticipated that future BESs systems will use a membranes-less design when applied for bioremediation purposes under field conditions.

The ability of the system to operate under harsh exposed conditions year round is an important consideration for field-deployed BESs. During the breakdown and biotransformation of organic contaminants, such as PAHs, incomplete degradation may form acidic metabolites such as naphthalic acid and salicylic acid. To test the resilience of a system, Adelaja et al. examined the effect of salinity and temperature on a system remediating the PAHs phenanthrene and benzene. There was a strong correlation between salinity and power density [150]. A decrease in performance occurred once the salinity reached $2.5 \%$. The average salinity of the Atlantic Ocean averages 3.5\%. If anodophilic biofilms become dehydrated, a decrease in the electron transfer rates due to 


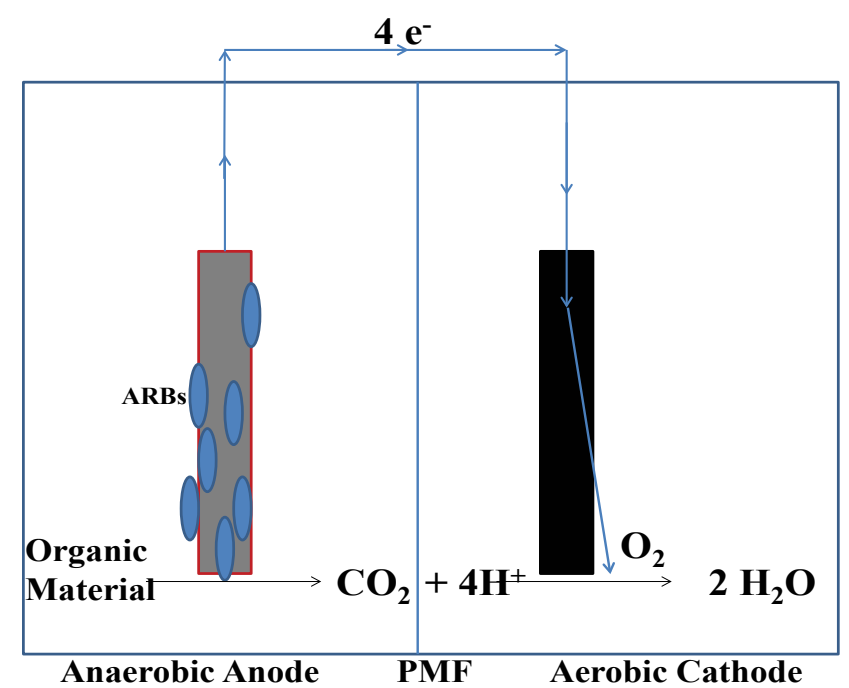

Figure 1: In a two chamber MFC, a biofilm of anode reducing bacteria (ARBs) on the anode catabolizes organics, including certain pollutants under anaerobic conditions. Electrode compartments are divided by a selective membrane (dashed line) to allow passage of protons from anode to cathode and inhibit diffusion of oxygen to the anode.

increased ionic power can occur [150]. When salinity increases, there is an increase in the ionic conductivity of the anolyte that decreases the internal resistance and over potential at the anode [151]. The optimal temperature parameter was between $20-40^{\circ} \mathrm{C}$, followed by a drop-off after the temperature hit $50^{\circ} \mathrm{C}$. As temperature increased to $40^{\circ} \mathrm{C}$ there was a 2 -fold increase in the rates of degradation, power density, and coulombic efficiency, attributable to a decrease in the activation energy to drive oxidation [150]. At over $50^{\circ} \mathrm{C}$ many bacteria are no longer able to endure conditions, leading to a drop-off in coulombic efficiency and power density. If natural sources of energy, like sunlight, can in the future be used to maintain BESs at around $40^{\circ} \mathrm{C}$ then catabolic rates for substrates like organic pollutants might be optimized.

Geobacter sulfurreducens has been shown to generate the highest current density of any exo-electrogenic species yet discovered. $G$. sulfurreducens showed a direct correlation between the biofilm conductivity and the density of the current [152]. The increase in biofilm conductivity reduced the resistance of electron flow across the biofilm and lowered the activation energy for electron transfer among biofilm and anode [152]. Therefore, maintaining an increased conductivity of the biofilm causes an increase in the power density of the MFC. This can be achieved by a decrease in charge transfer resistance, optimizing temperature, optimizing the surface load of platinum catalyst on the cathode, decreasing distance between electrodes, and current generation [153,154]. Engineers and microbiologists are actively investigating ways to improve BES performance in these regards.

Trinh et al. [154] showed G. sulfurreducens is capable of producing the highest production in current with acetate as the energy source. The maximum power density generated was between $418-470 \mathrm{~mW} / \mathrm{m}^{3}$ [155]. As the amount of platinum on the cathode electrode increases, the power density generated becomes increased. Metagenomic techniques have been applied for microbial community analysis and can now detect even uncultivable microbes [156]. Microbial consortia within a sludgefed microbial electrolysis cell were more diverse than microbes found in waste activated sludge alone and contained acid-producing species as well as exo-electrogens, most notably Geobacter [130]. From such novel sources new and useful species of exo-electrogens could be discovered that are able to degrade pollutants under extreme conditions.

\section{Bioelectrochemical Bioremediation}

Different types of BESs have been applied for bioremediation in controlled laboratory studies and limited field trials. In some situations, BES may have advantages over traditional bioremediation approaches. Yan et al. [155] showed that a sMFC with amorphous ferric hydroxide added to sediment was more capable of degradation of the PAHs phenanthrene and pyrene in freshwater sediment than the addition of Fe (III) alone to sediment. One strategy of the removal of $\mathrm{PAH}$ in sediments is the use of insoluble Fe (III) oxides; however, this strategy is slow and ineffective. In a sMFC, the anode serves as a stable, permanent electron acceptor and the oxidation of organic compounds in sediments is not limited by the supply of sediment electron acceptors. The resulting removal efficiency of phenanthrene using a sMFC with ferric hydroxide was $99.47 \pm 0.15 \%$ and pyrene was $94.79 \pm 0.63 \%$ over the course of 240 days [156]. One study showed that a variety of PAHs including naphthalene, acenaphthene and phenanthrene could be broken down using sMFCs under aerobic and anaerobic condition while generating electricity [157]. These systems could prove useful for natural habitat enrichment of difficult to culture bacteria possessing genes and pathways involved in bioremediation.

\section{Anode Oxidation of Organic Pollutants as Fuel}

In soil polluted with hydrocarbons, the arrangement of anodes in a MFC can also be influential in the process of breakdown [131]. Anodes that were horizontally arranged were $50.6 \%$ more effective after 135 days in removing total petroleum hydrocarbons compared with a vertical arrangement [158]. Both alkanes and PAHs were degraded at a significantly higher rate in the horizontal arrangement compared to the vertical arrangement due to the arrangement of the anodes. In the vertical arrangement, the diffusion direction of water ran parallel with the anode direction, which led to a reduction in the availability of substrate and a decrease in electricity generation [158]. In addition, this vertical arrangement of anodes limited the projected area of the cathode, which causes increased ion transfer resistance [158]. Phenanthrene (PHE), fluoranthene (FLU), pyrene (PYR), chrysene (CHR), and benzo[b]fluoranthene (BbF) accounted for $78 \%$ of the PAH concentration but after degradation, these PAHs had the highest levels of breakdown: PHE 24.6\%, FLU 4.6\%, PYR 8.5\%, CHR 10.4\%, and $\mathrm{BbF} 9.4 \%$ [158]. PAHs with high molecular weights had a slower rate of degradation at $7.8 \%$. Even a simple rod of conductive graphite inserted in contaminated sediment can significantly accelerate sediment biological activity and associated bioremediation. One such recent study reported a $12 \%$ increase in petroleum breakdown [159]. The conductive rod allows electrons derived from the oxidation of organic materials, like petroleum pollutants, to exit the reducing conditions of anaerobic sediments and travel upward to aerobic regions of the overlying water column. In the water column, electrons exiting the rod reduce oxygen in the presence of proteins to form water (Figure 2).

Another BES study investigated the ability of a MFC inserted in soil to remove phenol pollutants from a waterlogged soil [160]. A maximum $\mathrm{PD}$ of $29.45 \mathrm{~mW} / \mathrm{m}^{2}$ was generated from the system. Using a closed circuit setup, the MFC removed $90.1 \%$ of the phenol over the course of 10 days [160]. Compared to non-MFC conditions, the closed circuit MFC was able to degrade phenol 23-times greater. Chemical oxygen demand (COD) is the amount of oxygen required for the oxidation of organic substances in water. Huang et al. [160] showed a positive correlation between the breakdown of phenols and COD in 


\section{Atmosphere}

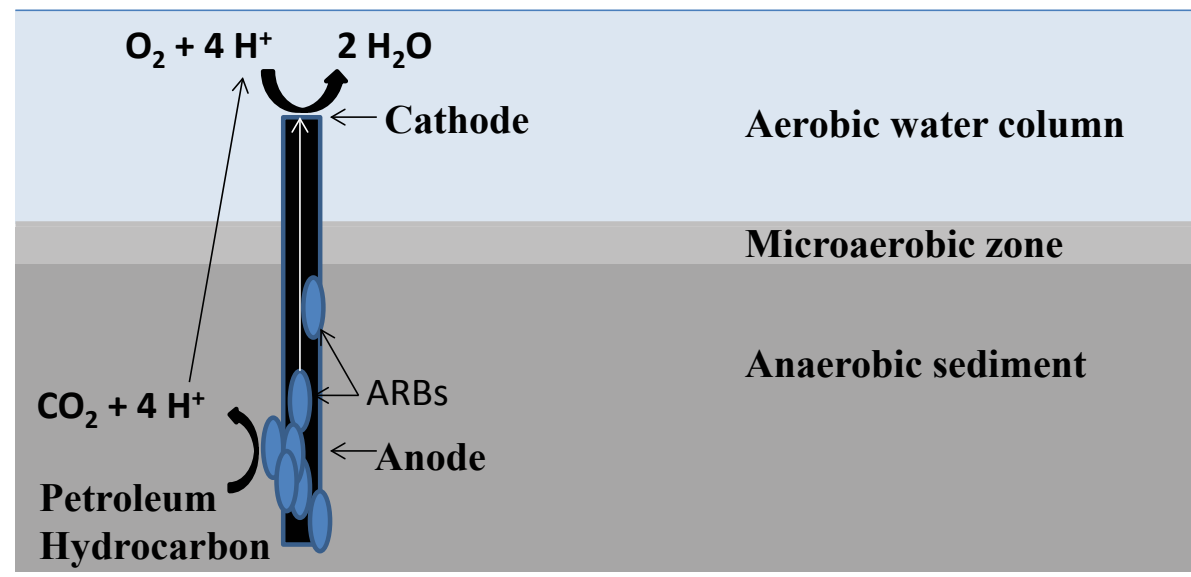

Figure 2: A rudimentary sediment MFC (sMFC) consists of an electrically conductive rod inserted in submerged sediments. Naturally present anode reducing bacteria (blue ovals) in anaerobic sediments catabolize organic material (ex. Petroleum Hydrocarbons) using anode as electron acceptor, generating a voltage and current flow to the upper cathode where exiting electrons reduce $\mathrm{O}_{2}$ in the presence of protons forming water.

\section{MFC testing.}

Pyridine is a heterocyclic compound found in wastewaters from industrial waste plants. Pyridine is difficult to break down naturally by bacteria due to its toxic effects on the bacteria. Zhang et al. [161] used a MFC that utilized graphite granules in each chamber to remediate pyridine. The use of pyridine as a fuel source generated a PD of $1.7 \mathrm{~W} /$ $\mathrm{m}^{3}$. The rate of degradation of pyridine in the MFC was $95 \%$ after a period of $24 \mathrm{~h}$ [161]. When the MFC was supplemented with glucose, the degradation rates of pyridine were higher in the MFC with graphite granules alone [161]. This study highlights the capabilities of MFCs to break down compounds that are recalcitrant and still have the ability generate electricity.

\section{Cathode Reduction of Pollutants}

BESs are beginning to be studied for bioremediation of herbicides and pesticides. Pentachlorophenol (PCP) is a recalcitrant toxin still in limited use as an insecticide and herbicide in the United States; although it is banned in many other countries. PCB can be effectively degraded and immobilized using MFCs. Interestingly, PCB metabolism occurs at the biocathode through a reductive mechanism that may involve Actinomycetes bacteria as biocatalysts [160]. BESs have recently been shown to accelerate mineralization of the herbicide isoproturon by up to 20 times [162]. Very little is known regarding the ability of BESs to remove pharmaceuticals and other trace organic contaminates; however, BESs were able to effectively attenuate the commonly used antibiotic trimethoprim from wastewater [163].

Current research examining the efficacy of BESs to bioremediate DDT is lacking, however, from our understanding of natural bioremediation of DDT and reductive dechlorination as the primary mechanism, it is plausible that BESs biocathodes could facilitate DDT bioremediation Work done with tetrachloroethene (PCE) and trichloroethene (TCE) serve as possible models. PCE and TCE are among the most common contaminants found in groundwater as a result of commercial, industrial, and military usage. These pollutants are federally recognized as toxic chemicals that pose significant health risks, including possible links as a carcinogen, Alzheimer's disease and congenital heart defects [164].

\section{Reductive Dechlorination of Organic Pollutants}

Microbial reductive dechlorination has been shown to be effective in the treatment of both compounds. In this process, anaerobic respiration occurs where the chlorinated organic compounds are utilized by bacteria as the TEA. This same process has been shown to be effective in the treatment of PCE. The breakdown of PCE uses an electron donor to break down the compound to TCE, cis-dichloroethylene (cisDCE), vinyl chloride (VC), and then non-toxic ethene or ethane [164]. During each step, a chlorine atom is replaced with hydrogen. Aulenta et al. [164] studied the ability of a mixed culture capable of reductive dechlorination to transfer electrons from an electrode to TCE. The microbes within the culture alone could not perform direct electron transfer. However, once the mediator methyl viologen, an electron shuttle, was added to the electrode, there was an immediate initiation in the dechlorination of TCE to cis-DCE [164]. A primary concern of this study was the use of methyl viologen, which is highly toxic. Strycharz et al. [165] were looking for a way to avoid the use of methyl viologen. They utilized Geobacter lovleyi, a species capable of direct electron transfer, and evaluated its ability to perform direct electron transfer from a graphite electrode to PCE. Once the electrode was set at -300 $\mathrm{mV}, \mathrm{G}$. lovleyi immediately began reducing PCE to cis-DCE without a mediator. Although the end product was only cis-DCE, this leaves open the possibility of further dechlorination using supplementation of natural bioremediation techniques [165]. Rabaey et al. have described a continuous flow MFC featuring a tubular design for electricity generation [133]. Conceivably, contaminated water in a tubular BES can be bioelectrochemically bioremediated. Further investigation into microorganisms able to completely dechlorinate PCE on BES electrodes is needed [166].

\section{BES Drawbacks and Limitations}

\section{Environmental limitations}

Conditions required for effective reduction of oxygen are not ideal conditions for the MFC system overall. The ambient temperature, low concentration of electrolytes, and the neutral $\mathrm{pH}$ optima of many exoelectrogens place strain limitations on the thermodynamic and kinetic performance of the cathode in the MFC [166]. Some microbes are able 
to carry out bioelectrochemical reactions at extreme pHs; for instance Acidithiobacillus ferrooxidans and Leptospirillum spp. [167]. Materials costs represent another limitation.

The large-scale construction and implementation of MFCs is hampered by the cost required to build systems. For optimal performance laboratory MFC cathodes typically contain platinum, representing a second major cost. MFCs require large electrode surface areas for supporting biofilms and the structure needs to be able to support the weight of the water and biofilm [134]. Outdoor MFC systems must be robust due to unpredictable weather events which can damage exposed components, like upper air cathodes. The materials used for electrodes typically include carbon cloth, carbon paper, carbon rods, plates, and granules. Delicate materials such as carbon cloth and paper make scaling up the system difficult due to a lack of durability or structural support. A possible means of overcoming this is coating conductive material on structurally sound materials to give more support to the structure [134]. Marine applications are particularly challenging due to the corrosive nature of seawater. For marine applications, noncorrosive metals, for example nickel, could be used on the cathode to delay or prevent the breakdown of the structure [134]. Since BES microbial biofilms take time to grow, startup time is often much slower than strictly chemical or physical remediation strategies.

Another challenge regarding the scale-up of the configuration of the MFC is the effect of increasing the distance between electrodes on the power produced from the system. Sangeetha and Muthukumar [168] showed that the MFC with the smallest distance between electrodes generated the greatest amount of power. Short distances between electrodes allow the protons generated in the anode during oxidation to travel a shorter distance to reach the cathode for the reduction of oxygen. If the distance between cathodes is increased, the proton transport is hindered which causes an increase in internal resistance due to a decreased available supply of protons [168]. A distance of 10 $\mathrm{cm}$ between the two electrodes generated a maximum of $8.1 \mathrm{~mW}$ of power, while a distance of $15 \mathrm{~cm}$ generated a maximum of $2.6 \mathrm{~mW}$ of power [168].

\section{Cost concerns of BES materials}

The cost of materials, in particular, on the cathode side, has been a major hurdle in the development of a large-scale BES. Carbon cloth is a costly material $\left(\sim \$ 1000 / \mathrm{m}^{2}\right)$ used for the electrode. Platinum is considered to be one of the best oxygen reducing catalysts, however, the cost is prohibitive $\left(\sim \$ 500 / \mathrm{m}^{2}\right)$ and it has a propensity to poisoning and inactivation. Nafion is a costly catalyst binder $\left(\sim \$ 700 / \mathrm{m}^{2}\right)$ widely used because of its high proton conductivity [169]. Early costs of BES systems were approximately $\$ 2000 / \mathrm{m}^{2}$ due to the high costs of these materials. Zhang et al. [169] examined the use of activated carbon (AC) to replace carbon cloth and platinum as a catalyst. AC is cheap $\left(\sim \$ 0.40 / \mathrm{m}^{2}\right)$ and more porous than graphite. The maximum power density generated with AC alone was $1220 \mathrm{~mW} / \mathrm{m}^{2}$; the maximum power density generated with a carbon cloth anode with platinum was $1060 \mathrm{~mW} / \mathrm{m}^{2}$. The performance of the AC cathode was increased due to the high surface area of the material. Zhang et al. [169] studied the effectiveness of Poly(dimethylsiloxane) or PDMS, a hydrophobic polymer that is highly permeable to oxygen as a replacement for Nafion as a binder. In addition, PDMS $\left(\sim \$ 1.50 / \mathrm{m}^{2}\right)$ is $0.23 \%$ the cost of Nafion. The maximum power density generated by Nafion and PDMS were comparable, however, the stability of the power density generated by PDMS was greater than Nafion. Over a period of 15 days, PDMS cathodes maintained a stable power density, while the Nafion binder cathode decreased power density by $40 \%$. This is due to the hydrophobicity of PDMS improving the oxygen mass transfer to the catalyst sites. The changes in these materials can bring the cost from $\$ 2000 / \mathrm{m}^{2}$ to $\sim \$ 43 / \mathrm{m}^{2}$ (Table 1 ).

\section{Cathode catalytic limitations}

The reduction reaction at the cathode of a BES can be identified as either aerobic or anaerobic based on the final electron acceptor used [171]. At the cathode of MFCs, oxygen, the terminal electron acceptor becomes reduced via electrons flowing through the circuit in the presence of protons. Reduction of oxygen occurs at the cathode and is provided by atmospheric oxygen which has a high redox potential of $0.82 \mathrm{mV}$. During the reduction of oxygen, there are two reactions that can take place, the desired production of water (Reaction 1), and the less desirable reaction forming hydrogen peroxide (Reaction 2) [171]. The formation of hydrogen peroxide creates intermediate and free radicals that are reactive and may damage the electrode metals.

$$
\mathrm{O}_{2}+4 \mathrm{H}^{+}+4 \mathrm{e}^{-} \rightarrow 2 \mathrm{H}_{2} \mathrm{O}
$$

Reaction 1: Reduction of oxygen to form water.

$$
2 \mathrm{O}_{2}+4 \mathrm{H}^{+}+4 \mathrm{e}^{-} \rightarrow 2 \mathrm{H}_{2} \mathrm{O}_{2}
$$

Reaction 2: Reduction of oxygen to form hydrogen peroxide which decreases of energy conversion efficiency and may damage transitional metals.

Oxygen depletion at the cathode can become a rate-limiting factor affecting metabolism, waste catabolism and electricity generation in BESs. In BES biocathodes, even when sufficient oxygen is available, the rate of $\mathrm{O}_{2}$ reduction is the limiting factor due to high over-potential for $\mathrm{O}_{2}$ reduction [172]. Ways of limiting over-potential are through the use of a metal or a biological cathode catalyst. Metal catalysts, like platinum, while effective at reducing required cathode overpotential, are expensive and non-renewable. Catalase and laccase enzymatic cathodes have been used to bolster MFC performance and catalase converts $\mathrm{H}_{2} \mathrm{O}_{2}$ to inert water plus $\mathrm{O}_{2}[173,174]$. While enzyme catalysts like laccase are lower in cost than precious metals, they must be purified, applied and are non-renewable and in-capable of self-repair. Biocathodes featuring living cells can be used to improve the performance of BESs, including MFCs [173]. Within biocathodes, distinct communities of organisms can develop, including microbes that facilitate oxygen reduction [175].Taxonomically diverse bacteria including Actinobacteria, Firmicutes, Bacteroidetes and Alpha-, Beta- and Gamma-proteobacteria are capable of catalyzing electron exchange [176]. Certain Actinobacteria are able to bioremediate the organocloride chlordane [177]. This suggests that BES biocathodes could be useful for the removal of organic pesticides.

\begin{tabular}{|c|c|c|c|}
\hline \multicolumn{2}{|c|}{ a] Early MFC System Cost in $\$ \mathbf{m}^{\mathbf{2}}$} & b] MFC Cost with New Materials in $\$ \mathbf{m}^{\mathbf{2}}$ \\
\hline Carbon Cloth & $\sim \$ 1000$ & Anode & Cost \\
\hline Platinum Catalyst & $\sim \$ 500$ & Cathode & $\sim \$ 20$ \\
\hline Binder & $\sim \$ 700$ & Binder & $\sim \$ 1.50$ \\
\hline Diffusion Layer & $\sim \$ 0.30$ & $\begin{array}{c}\text { Activated Carbon } \\
\text { [cathode/catalyst] }\end{array}$ & $\sim \$ 0.40$ \\
\hline Separator & $\sim \$ 1.00$ & Diffusion Layer & $\sim \$ 0.15$ \\
\hline Total & $\sim \$ 2200$ & Separator & $\sim \$ 1.00$ \\
\hline & & Total & $\sim \$ 43$ \\
\hline
\end{tabular}

Table 1: a) Breakdown of early MFC costs for materials in $\$ / m^{2}$ (USD), b) Breakdown of MFC costs using more recent and cost-effective materials. Adapted from $[169,170]$. 


\section{Outlook and Opportunities in Bioremediation}

\section{Hybrid systems}

Hybrid systems that integrate conventional with BES bioremediation have the potential to effectively remediate a greater spectrum of contaminates than either alone. Combining phytoremediation with MFC biocathodes could help overcome existing BES limitations. Cultivation of oxygenic phototrophs, such as algae or cyanobacteria, can provide a potential solution for overcoming $\mathrm{O}_{2}$ limitation at the cathode during daylight. Microbial phototrophs are the source of $75 \%$ of the Earth's oxygen, which occurs perpetually if there is accessibility to light to photolyse water and utilize $\mathrm{CO}_{2}$ from the environment to carry out photosynthesis [178]. Algae may be favorable over plants in that they have a short harvest cycle (1-10 days) [179]. In addition, they occupy less space and can be grown as an electrode adherent biofilm [180]. Algae can be subdivided into phytoplankton (microalgae) and the macrophytes (macroalgae). Phytoplanktons are green plants that are abundant in chlorophyll and lack lignin or cellulose but are composed of proteins, carbohydrates, and lipids [180]. Phytoplankton can be found in the oceans as well as grown in rivers. Macrophytes are composed of polysaccharides, unsaturated fatty acids, and cellulose [180]. Chlorella vulgaris is a phytoplankton composed of greater than $50 \%$ protein and is one of the fastest growing of the microalgae phytoplankton [178]. C. vulgaris facilitates uptake of electrons from BES cathodes while reducing $\mathrm{CO}_{2}$ to biomass [181]. Spirulina platensis is a cyanobacterium composed largely of proteins, $\beta$-carotene, vitamins and phycocyanin that could be useful in BESs [182].

The major limiting factor of a MFC is typically oxygen aeration at the cathode [183]. The use of a mechanical aerator or chemical cathode for the dissolution of oxygen has shortcomings, including complex construction, high cost while a chemical cathode can generate secondary pollution [179]. Oxygen generated via photolysis during oxygenic photosynthesis can act as an electron acceptor for the cathode while also removing the greenhouse gas $\mathrm{CO}_{2}$ [182]. Using bacteria at the anode chamber and C. vulgaris on the cathode during formed a potential difference of $70 \mathrm{mV}$ and a current of $1.0 \mu \mathrm{A} / \mathrm{mg}$, which generated a power density of $2.7 \mathrm{~mW} / \mathrm{m}^{2}$ [181]. A microalgae-based BES system has the potential to generate a continuous potential voltage and current to generate energy under light conditions. However, under night (dark) conditions, there can be a substantial drop off in power generation. In a modified MFC using C. vulgaris at the cathode to generate oxygen, the algal cathode side had increased levels of dissolved oxygen and voltage during periods of illumination, while there was a decrease in both during the absence of illumination [178]. The PD was increased $12.7 \%$ during a period of continued illumination; however, extended periods of illumination decreased the lifespan of the algae, which would suggest the need for a more intermittent illumination period. In comparison to an abiotic cathode, the PD of the biocathode was nearly 2.8 times greater [178].

Besides generating oxygen, algae have the ability to phytoremediate contaminants directly. Phytoplankton and macrophytes use a fast removal system initially through physicochemical adsorption, which is proceeded by a slower active absorption, accumulation, and degradation [184]. While algae are capable of bioremediating contaminants such as PAHs, they are also susceptible to toxicity. Algae have also been shown to accumulate metals such as aluminum, iron, and manganese from coal mines in their biomass. The iron concentration accumulated reached as high as $6.3 \%$ of the algal biomass [185]. Hong et al. [184] showed that the phytoplankton Skeletonema costatum and Nitzschia sp. had differing levels of tolerance to the PAHs phenanthrene (PHE) and fluoranthene (FLA); where S. costatum was more tolerant to the contaminants. Interestingly, when PHE and FLA were mixed, both species showed a higher efficiency in the bioremediation of the mixture compared to the removal of PHE or FLA alone [184]. FLA tended to show less remediation compared to PHE, which would indicate that FLA is more recalcitrant and stable [184]. Another PAH, benzo[a]pyrene $(\mathrm{BaP})$ is capable of being metabolized by Selenastrum capricornutum using a dioxygenase pathway [186]. The green algae S. capricornutum, Scenedesmus acutus and Ankistrodesmus braunii were able to metabolize $\mathrm{BaP}$ to dihydrodiols [186]. The degradation of $\mathrm{BaP}$ by algae is most affected by the levels of light emission and absorbance, the levels of PAHs, and the species and strain of the algae [186]. Phytoplankton species can oxidize naphthalene to 1-naphthol [187]. Chlorella sorokiniana TX 71105, Chlorella autotrophica strain 580, Dunaliella tertiolecta strain, Chlamydomonas angulosa and Ulva fasciata green algae can oxidize naphthalene. Various cyanobacteria (Oscillatoria sp.), diatoms (Amphora sp.), red algae (Porphyridium cruentum), and brown algae (Petalonia fascia) species are likewise able to break down naphthalene [187].

\section{Biosensing for remote process monitoring}

The technological revolutions in wireless networks, centralized computer data processing and BESs are swiftly converging on the field of environmental pollutant bioremediation. Beside their traditional application for renewable electricity generation, MFCs have been successfully adapted as biosensors. Shortly after developing the first practical and chemical toxin-free MFC in 1999, researchers under BH Kim demonstrated that MFCs could serve as sensitive biosensors; initially to measure the environmental parameter biochemical oxygen demand (BOD) [188]. Work by this group further revealed the presence of toxic chemicals, such as cyanide, could affect electrical output [189]. MFCs were subsequently adapted to detect and measure biodegradable organic matter [190].

As biosensors, MFCs are not limited to measuring chemical parameters. Physical parameters like illumination have been correlated with the electrical output of one type of MFC known as a photosynthetic MFC (p-MFC) [191]. Such light responsive p-MFCs could conceivably be adapted as herbicide pollution specific biosensors. These devices can electrically respond to carcinogenic herbicides including 3-3,4-dichlorophenyl]-1,1-dimethylurea (DCMU) which selectively inhibits photosystem II in phototrophic exo-electrogens [192,193]. One of the main drawbacks with traditional bioremediation is the general inability to monitor or quantify pollution removal progress. King et al. recently coupled computerized artificial neural-network based processing with microbial fuel cell [MFC]-based detection for identification and quantification of a mixture of organic pollutants including the endocrine-disruptor bisphenol-A [194]. By using the exo-electrogenic bacteria that energize MFC to power lower energy electronics a variety of tacks can be accomplished [195]. In the future, field grids of BES bioremediation systems could track and relay rates of pollutant removal. One challenge will be the low-cost development of networks of field sMFCs. As the cost of wireless transmitters and microcontrollers continues to fall, this challenge may be overcome. Shantaram, as early as 2005 demonstrated that a temperature sensor attached to a wireless data relay system could be powered by a MFC [196]. Research into wireless BES systems has preceded gradually over the past decade. Combining the documented capacity for bioremediation of BES's with their utility as biosensors and generators of renewable electricity can enable real-time monitoring with deeper insight into the progress of bioremediation at remote field locations. 
Thus, BES and BES-hybrid systems can supplement and enhance already effective tradition bioremediation methods that are being used to sustainably remove recalcitrant pollutants [197-203].

\section{Conclusion}

Worldwide expansion of petrochemical use in agriculture, industry and commercial products has led to high levels of pollution in many environments. The persistent effects of pollutants are far-reaching, from humans to animals to plants. Banned, recalcitrant agents, such as DDT, continue to adversely affect food chains and can affect hormone production and the central nervous system. Carcinogenic polycyclic aromatic hydrocarbons (PAHs) produced from combustion processes build up in soils rich in organic matter. Watersheds with low precipitation rates tend to be disproportionally affected by chemical pollutants. Newer classes of pollutants such as engineered nanoparticles and endocrine disruptors have been insufficiently studied to understand long-term effects on humans and environments. Attempts to chemically or physically remediate pollutants are often costly and difficult due to the recalcitrant nature of many chemical pollutants and/or the disruptive need to dig up sediments from ecosystems. Bioremediation represents an effective, economical, sustainable solution for in situ degradation of diverse types of pollutants in many situations. However, conventional bioremediation is limited in its capacity to breakdown chlorinated organics or HMW PAHs. In addition, the contaminants may be present at concentrations high enough to inhibit microbial growth and bioremediation efficacy. Overlapping pollutants may synergistically inhibit bioremediation. Another drawback to conventional bioremediation is the difficulty in process monitoring, particularly at remote field sites.

BES technology, unlike conventional bioremediation, is still at an early stage of development. MFCs, the most intensively studied type of BES, have proven effective in accelerating the breakdown of diverse organic pollutants, including pollutants that are highly recalcitrant in nature while generating renewable electricity from pollutant breakdown. Current research into the breakdown of PAHs and other compounds is promising but still at an early stage. It is not known if DDT can be effectively remediated using BES technology. To resolve issues of scaling up BESs, it will be critical to find materials that are more cost-effective and sturdier to support a larger structure in unpredictable weather conditions. As the distance increases between electrodes, a resolution needs to be found to maintain power generation in the system. Another problem that needs to be improved upon is the maintenance of levels of $\mathrm{O}_{2}$ at the MFC cathode. By integrating a biocathode that utilizes species of oxygenic phototrophs capable of phytoremediation, rates of MFCbased bioremediation could be accelerated while removing a broader range of pollutants from the soil and the water.

BESs in the future can be adapted for constructed wetlands as tubular flow BESs. Their appearance may be mitigated by their below grown localization and integrating of MFCs with phytoremediation. Plant-MFCs have been described in which photosynthesis and release of sugars fixed from $\mathrm{CO}_{2}$ and released roots bolster sMFC performance. MFC systems can efficiently remove toxic metals like chromium (VI) from soil via the mechanism of electrode adsorption. Extracellular polymeric substances (EPS) of biofilm forming bacteria can reductively remove and precipitate soluble metal as metal nanoparticles. Phototrophic algae and cyanobacteria are likewise able to bio-precipitate metals. Not only could these types of microbial biofilms remove metal pollutants, the metal-removing microbes might one day be exploited to deposit metal catalysts into electrodes for enhanced BES performance. Hybrid systems promise to be an active area of research for combining the low-cost, proven effectiveness of conventional bioremediation with the electrifying power of the newer BES technologies. Recent cost and size reductions in computing and wireless technologies can enable active process monitoring for the optimization of bioremediation at remote field site locations.

\section{References}

1. Jordaan SM (2012) Land and water impacts of oil sands production in Alberta. Environ Sci Technol 46: 3611-3617.

2. Bartzis J, Wolkoff P, Stranger M, Efthimiou G, Tolis El, et al. (2015) On organic emissions testing from indoor consumer products' use. J Hazard Mater 285: $37-45$.

3. Alharbi HA, Morandi G, Giesy JP, Wiseman SB (2016) Effect of oil sands process-affected water on toxicity of retene to early life-stages of Japanese medaka (Oryzias latipes). Aquat Toxicol 176: 1-9.

4. Pataranawat P, Parkpian P, Polprasert C, Delaune RD, Jugsujinda A (2007) Mercury emission and distribution: Potential environmental risks at a smallscale gold mining operation, Phichit Province, Thailand. J Environ Sci Health A Tox Hazard Subst Environ Eng 42: 1081-1093.

5. Jiao W, Ouyang W, Hao F, Lin C (2015) Anthropogenic impact on diffuse trace metal accumulation in river sediments from agricultural reclamation areas with geochemical and isotopic approaches. Sci Total Environ. 536: 609-615.

6. Raja R, Nayak AK, Shukla AK, Rao KS, Gautam P, et al. (2015) Impairment of soil health due to fly ash-fugitive dust deposition from coal-fired thermal power plants. Environ Monit Assess 187: 679.

7. Nadal M, Schuhmacher M, Domingo JL (2004) Levels of PAHs in soil and vegetation samples from Tarragona County, Spain. Environ Pollut 132: 1-11.

8. Klimkowicz-Pawlas A, Smreczak B, Ukalska-Jaruga A (2016) The impact of selected soil organic matter fractions on the PAH accumulation in the agricultural soils from areas of different anthropo-pressure. Environ Sci Pollut Res Int. In Press.

9. Chibuike GU, Obiora SC (2014) Heavy metal polluted soils: Effect on plants and bioremediation methods. Appl Environ Soil Sci 14: 1-12

10. Shahi A, Aydin S, Ince B, Ince O (2016) Evaluation of microbial population and functional genes during the bioremediation of petroleum-contaminated soil as an effective monitoring approach. Ecotoxicol Environ Saf 125: 153-160.

11. Purnomo AS, Mori T, Kamei I, Nishii T, Kondo R (2010) Application of mushroom waste medium from Pleurotus ostreatus for bioremediation of DDTcontaminated soil. Int Biodeterioration Biodegrad 64: 397-402.

12. Klaas EE, Belisle AA (1977) Organochlorine pesticide and polychlorinated biphenyl residues in selected fauna from a New Jersey salt marsh--1967 vs. 1973. Pestic Monit J 10: 149-158.

13. Gautam SK, Suresh S (2007) Studies on dechlorination of DDT (1-trichloro,2-bis(4-chlorophenyl)ethane) using magnesium/palladium bimetallic system. $J$ Hazard Mater 139: 146-153.

14. Hinck JE, Schmitt CJ, Chojnacki KA, Tillitt DE (2009) Environmental contaminants in freshwater fish and their risk to piscivorous wildlife based on a national monitoring program. Environ Monit Assess 152: 469-494.

15. Deribe E, Rosseland BO, Borgstrøm R, Salbu B, Gebremariam Z, et al. (2013) Biomagnification of DDT and its metabolites in four fish species of a tropical lake. Ecotoxicol Environ Saf 95: 10-18.

16. Harada T, Takeda M, Kojima S, Tomiyama N (2016) Toxicity and carcinogenicity of dichlorodiphenyltrichloroethane (DDT). Toxicol Res 32: 21-33.

17. Mattina MI, White J, Eitzer B, lannucci-Berger W (2002) Cycling of weathered chlordane residues in the environment: Compositional and chiral profiles in contiguous soil, vegetation and air compartments. Environ Toxicol Chem 21 : 281-288.

18. Jennings AA, Li Z (2015) Residential surface soil guidance applied worldwide to the pesticides added to the Stockholm Convention in 2009 and 2011. J Environ Manage 160: 226-240

19. Berger E, Haase P, Oetken M, Sundermann A (2016) Field data reveal low critical chemical concentrations for river benthic invertebrates. Sci Total Environ 544: 864-873.

20. Tinfo NS, Hotchkiss MG, Buckalew AR, Zorrilla LM, Cooper RL, et al. (2011) 
Understanding the effects of atrazine on steroidogenesis in rat granulosa and H295R adrenal cortical carcinoma cells. Reprod Toxicol 31: 184-193.

21. Buck JC, Hua J, Brogan WR 3rd, Dang TD, Urbina J, et al. (2015) Effects of pesticide mixtures on host-pathogen dynamics of the amphibian chytrid fungus. PLoS One 10: e0132832.

22. Greenhalgh S, Faeth $P$ (2001) A potential integrated water quality strategy for the Mississippi River Basin and the Gulf of Mexico. Scientific World Journal 1 Suppl 2: 976-983.

23. Sant'Anna CL, de Carvalho LR, Fiore MF, Silva-Stenico ME, Lorenzi AS, et al. (2010) Highly toxic Microcystis aeruginosa strain, isolated from São PauloBrazil, produce hepatotoxins and paralytic shellfish poison neurotoxins. Neurotox Res 19: 389-402.

24. Cha Y, Stow CA2 (2015) Mining web-based data to assess public response to environmental events. Environ Pollut 198: 97-99.

25. Ceballos-Laita L, Calvo-Begueria L, Lahoz J, Bes MT, Fillat MF, et al. (2015) $\hat{I}^{3}$ Lindane increases microcystin synthesis in Microcystis aeruginosa PCC7806. Mar Drugs 13: 5666-5680.

26. Corbel S, Mougin C, Bouaïcha N (2014) Cyanobacterial toxins: Modes of actions, fate in aquatic and soil ecosystems, phytotoxicity and bioaccumulation in agricultural crops. Chemosphere 96: 1-15.

27. Helmer SH, Kerbaol A, Aras P, Jumarie C, Boily M (2015) Effects of realistic doses of atrazine, metolachlor and glyphosate on lipid peroxidation and dietderived antioxidants in caged honey bees (Apis mellifera). Environ Sci Pollut Res 22: 8010-8021.

28. Williams BK, Semlitsch RD (2010) Larval responses of three mid-western anurans to chronic, low-dose exposures of four herbicides. Arch Environ Contam Toxicol 58: 819-827.

29. Schecter A, Quynh HT, Pavuk M, Päpke O, Malisch R, et al. (2003) Food as a source of dioxin exposure in the residents of Bien Hoa City, Vietnam. J Occup Environ Med 45: 781-788.

30. Huyen DT, Igarashi T, Shiraiwa T (2015) Vertical distribution of dioxins in soil of Bien Hoa airbase, Vietnam. Springerplus 4: 300.

31. Tavakoly Sany SB, Hashim R, Salleh A, Rezayi M, Karlen DJ, et al. (2015) Dioxin risk assessment: mechanisms of action and possible toxicity in human health. Environ Sci Pollut Res Int 22: 19434-19450.

32. Brodeur JC, Poliserpi MB, D'Andrea MF, Sánchez M (2014) Synergy between glyphosate- and cypermethrin-based pesticides during acute exposures in tadpoles of the common South American toad Rhinella arenarum. Chemosphere 112: 70-76.

33. Mohan SV, Kisa T, Ohkuma T, Kanaly RA, Shimizu Y (2006) Bioremediation technologies for treatment of $\mathrm{PAH}$-contaminated soil and strategies to enhance process efficiency. Rev Environ Sci Biotechnol 5: 347-374.

34. Wick AF, Haus NW, Sukkariyah BF, Haering KC, Daniels WL (2011) Remediation of PAH-contaminated soils and sediments: A literature review. Internal Research Document: 102

35. Pakpahan EN, Isa MH, Kutty SRM, Malakahmad A (2009) Effect of temperature on the formation and degradation of polycyclic aromatic hydrocarbons. International Conference on Emerging Technologies in Environmental Science and Engineering 1: 569-572.

36. Wilson SC, Jones KC (1993) Bioremediation of soil contaminated with polynuclear aromatic hydrocarbons (PAHs): A review. Environ Pollut 81: 229249.

37. Entrekin SA, Maloney KO, Kapo KE, Walters AW, Evans-White MA, et al. (2015) Stream vulnerability to widespread and emergent stressors: A focus on unconventional oil and gas. PLoS One 10: e0137416.

38. Birceanu O, Servos MR, Vijayan MM2 (2015) Bisphenol A accumulation in eggs disrupts the endocrine regulation of growth in rainbow trout larvae. Aquat Toxicol 161: 51-60.

39. Ying GG, Kookana RS, Dillon P (2003) Sorption and degradation of selected five endocrine disrupting chemicals in aquifer material. Water Res 37: 37853791.

40. Cheng D, Liu X, Wang L, Gong W, Liu G, et al. (2014) Seasonal variation and sediment-water exchange of antibiotics in a shallower large lake in North China. Sci Total Environ 476-477: 266-75.

41. Kappell AD, DeNies MS, Ahuja NH, Ledeboer NA, Newton RJ, et al. (2015)
Detection of multi-drug resistant Escherichia coli in the urban waterways of Milwaukee, WI. Front Microbiol 6: 336.

42. Agga GE, Arthur TM, Durso LM, Harhay DM, Schmidt JW (2015) Antimicrobialresistant bacterial populations and antimicrobial resistance genes obtained from environments impacted by livestock and municipal waste. PLoS One 21 :

43. Zemann M, Majewsky M, Wolf L (2016) Accumulation of pharmaceuticals in groundwater under arid climate conditions - Results from unsaturated column experiments. Chemosphere 154: 463-471.

44. Kumar N, Shah V, Walker VK (2011) Perturbation of an arctic soil microbial community by metal nanoparticles. J Hazard Mater 190: 816-822.

45. Wang X, Yang X, Chen S, Li Q, Wang W, et al. (2016) Zinc oxide nanoparticles affect biomass accumulation and photosynthesis in Arabidopsis. Front Plant Sci 12: 1243.

46. Peterson JW, Gu B, Seymour MD (2015) Surface interactions and degradation of a fluoroquinolone antibiotic in the dark in aqueous $\mathrm{TiO}_{2}$ suspensions. Sc Total Environ 532: 398-403.

47. Kulshreshtha S, Mathur N, Bhatnagar $P$ (2014) Mushroom as a product and their role in mycoremediation. AMB Express 4: 29.

48. Levin L, Diorio L, Grassi E, Forchiassin F (2012) Grape stalks as substrate for white rot fungi, lignocellulolytic enzyme production and dye decolorization. Rev Argent Microbiol 44: 105-112.

49. Gai YP, Zhang WT, Mu ZM, Ji XL (2014) Involvement of ligninolytic enzymes in degradation of wheat straw by Trametes trogii. J Appl Microbiol 117: 85-95.

50. Bosso L, Lacatena F, Cristinzio G, Cea M, Diez MC, et al. (2015) Biosorption of pentachlorophenol by Anthracophyllum discolor in the form of live fungal pellets. N Biotechnol 32: 21-25.

51. Bumpus JA, Aust SD (1987) Biodegradation of DDT [1-trichloro-,2-bis(4 chlorophenyl)ethane] by the white rot fungus Phanerochaete chrysosporium Appl Environ Microbiol 53: 2001-2008

52. Aust SD (1995) Mechanisms of degradation by white rot fungi. Environ Health Perspect 103 Suppl 5: 59-61.

53. Fakoya S (2014) Effect of the use of Pycnanthus angolensis and different supplements. Journal of Mycology 14: 1-4

54. Singh H (2006) Mycoremediation: Fungal bioremediation. Hoboken, N.J.: Wiley-Interscience Wiley Publishers.

55. Bumpus JA (1989) Biodegradation of polycyclic hydrocarbons by Phanerochaete chrysosporium. Appl Environ Microbiol 55: 154-158.

56. Lau KL, Tsang YY, Chiu SW (2003) Use of spent mushroom compost to bioremediate PAH-contaminated samples. Chemosphere 52: 1539-1546.

57. Migliore L, Fiori M, Spadoni A, Galli E (2012) Biodegradation of oxytetracycline by Pleurotus ostreatus mycelium: A mycoremediation technique. J Hazard Mater 215-216: 227-32.

58. Cvancarová M, Moeder M, Filipová A, Cajthaml T (2015) Biotransformation of fluoroquinolone antibiotics by ligninolytic fungi--Metabolites, enzymes and residual antibacterial activity. Chemosphere 136: 311-320.

59. Junghanns C, Moeder M, Krauss G, Martin C, Schlosser D (2005) Degradation of the xenoestrogen nonylphenol by aquatic fungi and their laccases. Microbiology 151: 45-57.

60. Zhang C, Li M, Chen X, Li M3 (2015) Edible fungus degrade bisphenol A with no harmful effect on its fatty acid composition. Ecotoxicol Environ Saf 118: 126132.

61. Macellaro G, Pezzella C, Cicatiello P, Sannia G, Piscitelli A (2014) Fungal laccases degradation of endocrine disrupting compounds. Biomed Res Int 2014: 614038

62. Singh VK, Singh MP (2014) Bioremediation of vegetable and agro-wastes by Pleurotus ostreatus: A novel strategy to produce edible mushroom with enhanced yield and nutrition. Cell Mol Biol (Noisy-le-grand) 60: 2-6.

63. Almeida SM, Umeo SH, Marcante RC, Yokota ME, Valle JS, et al. (2015) Iron bioaccumulation in mycelium of Pleurotus ostreatus. Braz J Microbiol 46: 195200.

64. Chen GQ, Zeng GM, Tu X, Huang GH, Chen YN (2005) A novel biosorbent: Characterization of the spent mushroom compost and its application for removal of heavy metals. J Environ Sci (China) 17: 756-760. 
Citation: Pisciotta JM, Dolceamore JJ (2016) Bioelectrochemical and Conventional Bioremediation of Environmental Pollutants. J Microb Biochem Technol 8: 327-343. doi: 10.4172/1948-5948.1000306

65. Tay CC, Liew HH, Redzwan G, Yong SK, Surif S, et al. (2011) Pleurotus ostreatus spent mushroom compost as green biosorbent for nickel (II) biosorption. Water Sci Technol 64: 2425-2432

66. Saier JR, Trevors JT (2010) Phytoremediation. Water Air Soil Pollut 205: 61-63.

67. Pilon-Smits E (2005) Phytoremediation. Annu Rev Plant Biol 56: 15-39.

68. Wu N, Zhang S, Huang H, Shan X, Christie P, et al. (2008) DDT uptake by arbuscular mycorrhizal alfalfa and depletion in soil as influenced by soil application of a non-ionic surfactant. Environ Pollut 151: 569-575.

69. Rissato SR, Galhiane MS, Fernandes JR, Gerenutti M, Gomes HM, et al. (2015) Evaluation of Ricinus communis $\mathrm{L}$. for the phytoremediation of polluted soil with organochlorine pesticides. Biomed Res Int 2015: 549863.

70. Liu R, Xiao N, Wei S, Zhao L, An J (2014) Rhizosphere effects of PAHcontaminated soil phytoremediation using a special plant named Fire Phoenix. Sci Total Environ 473-474: 350-8.

71. Kraus JJ, Munir IZ, McEldoon JP, Clark DS, Dordick JS (1999) Oxidation of polycyclic aromatic hydrocarbons catalyzed by soybean peroxidase. Appl Biochem Biotechnol. 80: 221-230.

72. Chandra K, Sekhar K, Kamala CT, Chary NS, Sastry AR, et al. (2004) Removal of lead from aqueous solutions using an immobilized biomaterial derived from a plant biomass. J Hazard Mater 108: 111-117.

73. Jaiswar S, Kazi MA, Mehta S (2015) Bioaccumulation of heavy metals by freshwater algal species of Bhavnagar, Gujarat, India. J Environ Biol 36: 13611366 .

74. Olguín EJ, Sánchez-Galván G (2012) Heavy metal removal in phytofiltration and phycoremediation: the need to differentiate between bioadsorption and bioaccumulation. N Biotechnol 30: 3-8.

75. Sode S, Bruhn A, Balsby TJ, Larsen MM, Gotfredsen A, et al. (2013) Bioremediation of reject water from anaerobically digested waste water sludge with macroalgae (Ulva lactuca, Chlorophyta). Bioresour Technol 146: 426-435.

76. Ajayan KV, Selvaraju M, Unnikannan P, Sruthi P (2015) Phycoremediation of tannery wastewater using microalgae Scenedesmus species. Int J Phytoremediation 17: 907-916.

77. Helder M, Strik DP, Hamelers HV, Kuhn AJ, Blok C, et al. (2010) Concurren bio-electricity and biomass production in three plant-microbial fuel cells using Spartina anglica, Arundinella anomala and Arundo. Bioresour Technol 101 3541-3547.

78. Sudha SS, Rajamanickam K, Rengaramanujam J (2013) Microalgae mediated synthesis of silver nanoparticles and their antibacterial activity against pathogenic bacteria. Indian J Exp Biol 51: 393-399.

79. Habibul N, Hu Y, Wang YK, Chen W, et al. (2016) Bioelectrochemical Chromium(VI) removal in plant-microbial fuel cells. Environ Sci Technol 50: 3882-3889.

80. Salunke BK, Sawant SS, Lee SI, Kim BS (2016) Microorganisms as efficient biosystem for the synthesis of metal nanoparticles: Current scenario and future possibilities. World J Microbiol Biotechnol 32: 88

81. Zhang H, Jiang X, Lu L, Xiao W (2015) Biodegradation of polychlorinated biphenyls (PCBs) by the novel identified cyanobacterium Anabaena PD-1. PLoS One 10: e0131450.

82. González R, García-Balboa C, Rouco M, Lopez-Rodas V, Costas E (2012) Adaptation of microalgae to lindane: A new approach for bioremediation. Aquat Toxicol 109: 25-32.

83. Srivastava J, Naraian R, Kalra SJS, Chandra H (2014) Advances in microbia bioremediation and the factors influencing the process. Int $\mathrm{J}$ Environ Sci Technol 11: 1787-1800

84. El-Bestawy E, Mansy AH, Attia AM, Zahran H (2014) Biodegradation of persistent chlorinated hydrocarbons using selected freshwater bacteria. J Bioremed Biodeg 5: 1-6.

85. Benyahia F, Embaby AS (2016) Bioremediation of crude oil contaminated desert soil: Effect of biostimulation, bioaugmentation and bioavailability in biopile treatment systems. Int J Environ Res Public Health 13: 219.

86. Mota R, Rossi F, Andrenelli L, Pereira SB, De Philippis R, et al. (2016) Released polysaccharides (RPS) from Cyanothece sp. CCY 0110 as biosorbent for heavy metals bioremediation: interactions between metals and RPS binding sites. Appl Microbiol Biotechnol In Press.
87. Lloyd, JR (2002) Bioremediation of metals; the application of micro-organisms that make and break minerals. Microbiol Today 29: 67-69.

88. Peixoto RS, Vermelho AB, Rosado AS (2011) Petroleum-degrading enzymes: Bioremediation and new prospects. Enzyme Res 2011: 475193.

89. Huang K, Chen C, Shen Q, Rosen BP, Zhao FJ (2015) Genetically engineering Bacillus subtilis with a heat-resistant arsenite methyltransferase for bioremediation of arsenic-contaminated organic waste. Appl Environ Microbiol 81: 6718-6724

90. Holliger C, Schraa G (1994) Physiological meaning and potential for application of reductive dechlorination by anaerobic bacteria. FEMS Microbiol Rev 15: 297-305

91. Aislabie JM, NK Richards, HL Boul (1997) Microbial degradation of DDT and its residues, A review, New Zealand. Journal of Agricultural Research 40: 269-282.

92. Mendel JL, Walton MS (1966) Conversion of $p, p^{\prime}$-DDT to $p, p^{\prime}$-DDD by intestinal flora of the rat. Science 151: 1527-1528.

93. Nadeau LJ, Menn FM, Breen A, Sayler GS (1994) Aerobic degradation of 1-trichloro-,2-bis(4-chlorophenyl)ethane (DDT) by Alcaligenes eutrophus A5 Appl Environ Microbiol 60: 51-55.

94. Ahmad M, Roberts JN, Hardiman EM, Singh R, Eltis LD, et al. (2011) Identification of DypB from Rhodococcus jostii RHA1 as a lignin peroxidase. Biochemistry 50: 5096-5107.

95. Bajaj A, Mayilraj S, Mudiam MK, Patel DK, Manickam N (2014) Isolation and functional analysis of a glycolipid producing Rhodococcus sp. strain IITR03 with potential for degradation of 2,1,1-trichloro-3,2-bis(4-chlorophenyl)ethane (DDT). Bioresour Technol 167: 398-406.

96. Pan X, Lin D, Zheng Y, Zhang Q, Yin Y, et al. (2016) Biodegradation of DDT by Stenotrophomonas sp. DDT-1: Characterization and genome functional analysis. Sci Rep 6: 21332

97. Li FB, Li XM, Zhou SG, Zhuang L, Cao F, et al. (2010) Enhanced reductive dechlorination of DDT in an anaerobic system of dissimilatory iron-reducing bacteria and iron oxide. Environ Pollut 158: 1733-1740.

98. Jin X, Wang F, Gu C, Yang X, Kengara FO, et al. (2015) The interactive biotic and abiotic processes of DDT transformation under dissimilatory iron-reducing conditions. Chemosphere 138: 18-24.

99. Pandit S, Khilari S, Roy S, Pradhan D, Das D (2014) Improvement of powe generation using Shewanella putrefaciens mediated bioanode in a single chambered microbial fuel cell: effect of different anodic operating conditions. Bioresour Technol 166: 451-457.

100. Schmidt KR, Gaza S, VoropaevA, ErtI S, Tiehm A(2014)Aerobic biodegradation of trichloroethene without auxiliary substrates. Water Res 59: 112-118.

101. Laskin Al, Sariaslani S, Gadd GM (2008) Advances in Applied Microbiology 65: 35-36.

102. Li F, Guo S, Hartog N, Yuan Y, Yang X (2016) Isolation and characterization of heavy polycyclic aromatic hydrocarbon-degrading bacteria adapted to electrokinetic conditions. Biodegradation 27: 1-13.

103. Zafra G, Absalón ÁE, Cuevas MDC, Cortés-Espinosa DV (2014) Isolation and selection of a highly tolerant microbial consortium with potential for PAH biodegradation from heavy crude oil-contaminated soils. Water Air Soil Pol 225: 1-18.

104. Leys NM, Bastiaens L, Verstraete W, Springael D (2005) Influence of the carbon/nitrogen/phosphorus ratio on polycyclic aromatic hydrocarbon degradation by Mycobacterium and Sphingomonas in soil. Appl Microbiol Biotechnol 66: 726-736.

105. Liu Z, Liu J (2013) Evaluating bacterial community structures in oil collected from the sea surface and sediment in the northern Gulf of Mexico after the Deep water Horizon oil spill. Microbiology Open 2: 492-504.

106. Hanson BT, Yagi JM, Jeon CO, Madsen EM (2012) Role of nitrogen fixation in the autecology of Polaromonas naphthalenivorans in contaminated sediments. Environ Microbiol 14: 1544-1557.

107. Liu Z, Liu J (2013) Evaluating bacterial community structures in oil collected from the sea surface and sediment in the northern Gulf of Mexico after the Deep water Horizon oil spill. Microbiology Open 2: 492-504.

108. Gorby YA, Yanina S, McLean JS, Rosso KM, Moyles D, et al. (2006) Electrically conductive bacterial nanowires produced by Shewanella oneidensis strain MR-1 and other microorganisms 103: 11358-11363. 
109. Rabaey K, Angenet L, Schroder U (2010) Bioelectrochemical systems: From extracellular electron transfer to biotechnological application. 1-2 London: IWA Publishing.

110. Reguera G, McCarthy KD, Mehta T, Nicoll JS, Tuominen MT, et al. (2005) Extracellular electron transfer via microbial nanowires. Nature 435: 1098-1101.

111. Logan BE, Rabaey K (2012) Conversion of wastes into bioelectricity and chemicals by using microbial electrochemical technologies. Science 337: 686690.

112. Boesen T, Nielsen LP (2013) Molecular dissection of bacterial nanowires. MBio 4: 270-273.

113. Ding DW, Xu J, Li L, Xie JM, Sun X (2014) Identifying the potential extracellular electron transfer pathways from a c-type cytochrome network. Mol Biosyst 10: 3138-3146.

114. Caccavo F, Lonergan DJ, Lovley DR, Davis M, Stolz, JF et al. (1994) Geobacter sulfurreducens $\mathrm{sp}$. nov., a hydrogen-and acetate-oxidizing dissimilatory metalreducing microorganism. Appl Environ Microbiol 60: 3752-3759.

115. Lovley DR, Giovannoni SJ, White DC, Champine JE, Phillips EJ, et al. (1993) Geobacter metallireducens gen. nov. sp. nov., a microorganism capable of coupling the complete oxidation of organic compounds to the reduction of iron and other metals. Arch Microbiol 159: 336-344.

116. Venkateswaran K, Moser DP, Dollhopf ME, Lies DP, Saffarini DA, et al. (1999) Polyphasic taxonomy of the genus Shewanella and description of Shewanella oneidensis sp. nov. Int J Syst Bacteriol 49 Pt 2: 705-724.

117. Yang Y, Xu M, Guo J, Sun G (2012) Bacterial extracellular electron transfer in bioelectrochemical systems. Process Biochem 47: 1707-1714.

118. Deng LF, Li FB, Zhou SG, Huang D, Ni J (2010) A study of electron-shuttle mechanism in Klebsiella pneumoniae based-microbial fuel cells. Chinese Sci Bull 55: 99-104

119. Turick CE, Tisa LS, Caccavo Jr F (2002) Melanin production and use as a soluble electron shuttle for Fe (III) oxide reduction and as a terminal electron acceptor by Shewanella algae BrY. Appl Environ Microbiol 68: 2436-2444.

120.Wu C, Cheng YY, Li BB, Li WW, Li DB, et al. (2013) Electron acceptor dependence of electron shuttle secretion and extracellular electron transfer by Shewanella oneidensis MR-1. Bioresour Technol 136: 711-714.

121. Rosenbaum M, Aulenta F, Villano M, Angenent LT (2011) Cathodes as electron donors for microbial metabolism: Which extracellular electron transfer mechanisms are involved? Bioresource Technol 102: 324-333.

122.Lovley DR (2011) Powering microbes with electricity: direct electron transfer from electrodes to microbes. Environ Microbiol Rep 3: 27-35.

123. Lovley DR, Nevin KP (2011) A shift in the current: new applications and concepts for microbe-electrode electron exchange. Curr Opin Biotechnol 22: 441-448.

124. Weber KA, Achenbach LA, Coates JD (2006) Microorganisms pumping iron: Anaerobic microbial iron oxidation and reduction. Nat Rev Microbiol 4: 752 764.

125. Pisciotta JM, Zaybak Z, Call DF, Nam JY, Logan BE (2012) Enrichment of microbial electrolysis cell biocathodes from sediment microbial fuel cell bioanodes. Appl Environ Microbiol 78: 5212-5219.

126.Zaybak Z, Pisciotta JM, Tokash JC, Logan BE (2013) Enhanced start-up of anaerobic facultatively autotrophic biocathodes in bioelectrochemical systems. J Biotechnol 168: 478-485.

127. Hamelers HV, Ter Heijne A, Sleutels TH, Jeremiasse AW, Strik DP, et al. (2010) New applications and performance of bioelectrochemical systems. Appl Microbiol Biotechnol 85: 1673-1685.

128. Liu RH, Sheng GP, Sun M, Zang GL, Li WW, et al. (2011) Enhanced reductive degradation of methyl orange in a microbial fuel cell through cathode modification with redox mediators. Appl Microbiol Biotechnol 89: 201-208.

129. Huang L, Chai X, Quan X, Logan BE, Chen G (2012) Reductive dechlorination and mineralization of pentachlorophenol in biocathode microbial fuel cells. Bioresour Technol 111: 167-174.

130. Lu L, Xing D, Ren N (2012) Pyrosequencing reveals highly diverse microbial communities in microbial electrolysis cells involved in enhanced $\mathrm{H}_{2}$ production from waste activated sludge. Water research 46: 2425-2434.
131. Morris JM, Jin S, Crimi B, Pruden A (2009) Microbial fuel cell in enhancing anaerobic biodegradation of diesel. Chem Eng J 146: 161-167.

132. Rabaey K, Rozendal RA (2010) Microbial electrosynthesis - revisiting the electrical route for microbial production. Nat Rev Microbiol 8: 706-716.

133. Rabaey K, Clauwaert P, Aelterman P, Verstraete W (2005) Tubular microbial fuel cells for efficient electricity generation. Environ Sci Technol 39: 8077-8082.

134. Logan BE, Regan JM (2006) Microbial fuel cells--challenges and applications Environ Sci Technol 40: 5172-5180.

135. Call D, Logan BE (2008) Hydrogen production in a single chamber microbia electrolysis cell lacking a membrane. Environ Sci Technol 42: 3401-3406.

136. Clauwaert $P$, Verstraete $W(2009)$ Methanogenesis in membrane less microbial electrolysis cells. Appl Microbiol Biotechnol 82: 829-836.

137. Tice CR, Y Kim (2014) Methanogenesis control by electrolytic oxygen production in microbial electrolysis cells. International Journal of Hydrogen Energy 39: 3079-3086.

138. Guzman JJ, Cooke KG, Gay MO, Radachowsky SE, Girguis PR, et al. (2010) Benthic microbial fuel cells: long-term power sources for wireless marine sensor networks. In SPIE Defense, Security, and Sensing 1: 1-12.

139. Lovley DR (2006) Microbial fuel cells: novel microbial physiologies and engineering approaches. Curr Opin Biotechnol 17: 327-332.

140. Tender LM, Gray SA, Groveman, E, Lowy DA, Kauffman P et al. (2008) The first demonstration of a microbial fuel cell as a viable power supply: Powering a meteorological buoy. J Power Sources 179: 571-575.

141. Corbella C, Garfí M, Puigagut J (2014) Vertical redox profiles in treatment wetlands as function of hydraulic regime and macrophytes presence: surveying the optimal scenario for microbial fuel cell implementation. Sci Total Environ 1: 754-758.

142. Bellagamba M, Cruz Viggi C, Ademollo N, Rossetti S, Aulenta F (2016) Electrolysis-driven bioremediation of crude oil-contaminated marine sediments. N Biotechnol.

143. Ringeisen BR, Henderson E, Wu PK, Pietron J, Ray R, et al. (2006) High power density from a miniature microbial fuel cell using Shewanella oneidensis DSP10. Environ Sci Technol 40: 2629-2634.

144.Pant D, Van Bogaert G, Diels L, Vanbroekhoven K (2010) A review of the substrates used in microbial fuel cells (MFCs) for sustainable energy production. Bioresour Technol 101: 1533-1543.

145.Logan BE, Hamelers B, Rozendal R, Schröder U, Keller J, et al. (2006) Microbial fuel cells: methodology and technology. Environ Sci Technol 40: 5181-5192.

146. Chae KJ, Choi MJ, Lee JW, Kim KY, Kim IS (2009) Effect of different substrates on the performance, bacterial diversity and bacterial viability in microbial fue cells. Bioresource Technol. 100: 3518-3525

147. Cheng S, Liu H, Logan BE (2006) Power densities using different cathode catalysts (Pt and CoTMPP) and polymer binders (Nafion and PTFE) in single chamber microbial fuel cells. Environ Sci Technol 40: 364-369.

148. Oh S, Min B, Logan BE (2004) Cathode performance as a factor in electricity generation in microbial fuel cells. Environ Sci Technol 38: 4900-4904.

149. Liu H, Logan BE (2004) Electricity generation using an air-cathode single chamber microbial fuel cell in the presence and absence of a proton exchange membrane. Environ Sci Technol 38: 4040-4046.

150.Adelaja O, Keshavarz T, Kyazze G3 (2015) The effect of salinity, redox mediators and temperature on anaerobic biodegradation of petroleum hydrocarbons in microbial fuel cells. J Hazard Mater 283: 211-217.

151.Lefebvre O, Tan Z, Kharkwal S, Ng HY (2012) Effect of increasing anodic $\mathrm{NaCl}$ concentration on microbial fuel cell performance. Bioresour Technol 112: 336-340.

152. Malvankar NS, Tuominen MT, Lovley DR (2012) Biofilm conductivity is a decisive variable for high-current-density Geobacter sulfurreducens microbial fuel cells. Energ Environ Sci 5: 5790-5797.

153. He Z, Shao H, Angenent LT (2007) Increased power production from a sediment microbial fuel cell with a rotating cathode. Biosens Bioelectron 22 : 3252-3255

154. Trinh NT, Park JH, Kim BW (2009) Increased generation of electricity in a 
microbial fuel cell using Geobacter sulfurreducens. Korean J Chem Eng 26 : 748-753.

155. Yi H, Nevin KP, Kim BC, Franks AE, Klimes A, et al. (2009) Selection of a variant of Geobacter sulfurreducens with enhanced capacity for current production in microbial fuel cells. Biosens Bioelectron 24: 3498-3503.

156. Yan Z, Song N, Cai H, Tay JH, Jiang H (2012) Enhanced degradation of phenanthrene and pyrene in freshwater sediments by combined employment of sediment microbial fuel cell and amorphous ferric hydroxide. J Hazard Mater 199-200: 217-25.

157. Quince C, Lanzén A, Curtis TP, Davenport RJ, Hall N, et al. (2009) Accurate determination of microbial diversity from 454 pyrosequencing data. Nat Methods 6: 639-641.

158. Sherafatmand M, Ng HY2 (2015) Using sediment microbial fuel cells (SMFCs) for bioremediation of polycyclic aromatic hydrocarbons (PAHs). Bioresour Technol 195: 122-130.

159. Zhang Y, Wang X, Li X, Cheng L, Wan L, et al. (2014) Horizontal arrangement of anodes of microbial fuel cells enhances remediation of petroleum hydrocarbon-contaminated soil. Environ Sci Pollut R 22: 2335-2341.

160. Cruz-Viggi C, Presta E, Bellagamba M, Kaciulis S, Balijepalli SK et al. (2015) The "Oil-Spill Snorkel": an innovative bioelectrochemical approach to accelerate hydrocarbons biodegradation in marine sediments. Front Microbiol 4: 881 .

161. Huang DY, Zhou SG, Chen Q, Zhao B, Yuan Y et al. (2011) Enhanced anaerobic degradation of organic pollutants in a soil microbial fuel cell. Chem Eng J 172: 647-653.

162.Zhang C, Li M, Liu G, Luo H, Zhang R (2009) Pyridine degradation in the microbial fuel cells. J Hazard Mater 172: 465-471.

163.Rodrigo Quejigo J, Dörfler U, Schroll R, Esteve-Núñez A, et al. (2016) Stimulating soil microorganisms for mineralizing the herbicide isoproturon by means of microbial electroremediating cells. Microb Biotechnol 9: 369-380.

164. Werner CM, Hoppe-Jones C, Saikaly PE, Logan BE, Amy GL (2015) Attenuation of trace organic compounds (TOrCs) in bioelectrochemical systems. Water Res 73: 56-67.

165. Aulenta F, Catervi A, Majone M, Panero S, Reale P, et al. (2007) Electron transfer from a solid-state electrode assisted by methyl viologen sustains efficient microbial reductive dechlorination of TCE. Environmental Science \& Technology 41: 2554-2559.

166. Strycharz SM, Woodard TL, Johnson JP, Nevin KP, Sanford RA, et al. (2008) Graphite electrode as a sole electron donor for reductive dechlorination of tetrachlorethene by Geobacter lovleyi. Applied and environmental microbiology 74: 5943-5947.

167. Sulonen ML, Kokko ME, Lakaniemi AM, Puhakka JA2 (2015) Electricity generation from tetrathionate in microbial fuel cells by acidophiles. J Hazard Mater 284: 182-189.

168. García-Muñoz J, Amils R, Fernández VM, De Lacey AL, Malki M (2011) Electricity generation by microorganisms in the sediment-water interface of an extreme acidic microcosm. Int Microbiol 14: 73-81.

169. Sangeetha T, Muthukumar M (2013) Influence of electrode material and electrode distance on bioelectricity production from sago-processing wastewater using microbial fuel cell. Environ Prog Sustainable Energy 32 390-395.

170.Zhang F, Chen G, Hickner MA, Logan BE (2012) Novel anti-flooding poly (dimethylsiloxane) (PDMS) catalyst binder for microbial fuel cell cathodes. Journal of Power Sources 218: 100-105.

171. Zhang F, Cheng S, Pant D, Van Bogaert G, Logan BE (2009) Power generation using an activated carbon and metal mesh cathode in a microbial fuel cell. Electrochemistry Communications 11: 2177-2179.

172. Rismani-Yazdi H, Carver SM, Christy AD, Tuovinen $\mathrm{OH}$ (2008) Cathodic limitations in microbial fuel cells: An overview. J Power Sources 180: 683-694.

173. Ter Heijne A, Strik DP, Hamelers HV, Buisman CJ (2010) Cathode potential and mass transfer determine performance of oxygen reducing biocathodes in microbial fuel cells. Environ Sci Technol 44: 7151-7156.

174.Ammam M, Fransaer $\mathrm{J}$ (2013) Combination of laccase and catalase in construction of $\mathrm{H}_{2} \mathrm{O}_{2}-\mathrm{O}_{2}$ based biocathode for applications in glucose biofuel cells. Biosens Bioelectron 39: 274-281.
175. Tominaga M, Sasaki A, Togami M (2015) Laccase bioelectrocatalyst at a steroid-type biosurfactant-modified carbon nanotube interface. Anal Chem 87: 5417-5421.

176. Strycharz-Glaven SM, Glaven RH, Wang Z, Zhou J, Vora GJ, et al. (2013) Electrochemical investigation of a microbial solar cell reveals a nonphotosynthetic biocathode catalyst. Appl Environ Microbiol 79: 3933-3942.

177. Lyautey E, Cournet A, Morin S, Boulêtreau S, Etcheverry L, et al. (2011) Electroactivity of phototrophic river biofilms and constitutive cultivable bacteria. Appl Environ Microbiol 77: 5394-5401.

178. Fuentes MS, Colin VL, Amoroso MJ, Benimeli CS (2016) Selection of an actinobacteria mixed culture for chlordane remediation. Pesticide effects on microbial morphology and bioemulsifier production. J Basic Microbiol. 56: 127-137.

179. Wu XY, Song TS, Zhu XJ, Wei P, Zhou CC (2013) Construction and operation of microbial fuel cell with Chlorella vulgaris biocathode for electricity generation. Appl Biochem Biotechnol 171: 2082-2092.

180. Schenk PM, Thomas-Hall SR, Stephens E, Marx UC, Mussgnug JH, et al. (2008) Second generation biofuels: High-efficiency microalgae for biodiesel production. Bioene Res. 1: 20-43.

181. Velasquez-Orta SB, Curtis TP, Logan BE (2009) Energy from algae using microbial fuel cells. Biotechnol Bioeng 103: 1068-1076.

182. Powell EE, Mapiour ML, Evitts RW, Hill GA (2009) Growth kinetics of Chlorella vulgaris and its use as a cathodic half-cell. Bioresour Technol 100: 269-274.

183. Fu CC, Su CH, Hung TC, Hsieh CH, Suryani D, et al. (2009) Effects of biomass weight and light intensity on the performance of photosynthetic microbial fuel cells with Spirulina platensis. Bioresource Technol 100: 4183-4186.

184. Mohan SV, Srikanth S, Chiranjeevi P, Arora S, Chandra R (2014) Algal biocathode for in situ terminal electron acceptor (TEA) production: Synergetic association of bacteria-microalgae metabolism for the functioning of biofuel cell. Bioresour Technol 166: 566-574.

185. Hong YW, Yuan DX, Lin QM, Yang TL (2008) Accumulation and biodegradation of phenanthrene and fluoranthene by the algae enriched from a mangrove aquatic ecosystem. Mar Pollut Bull 56: 1400-1405.

186. Freitas A, Schneider IH, Schwartzbold A (2011) Biosorption of heavy metals by algal communities in water streams affected by the acid mine drainage in the coal-mining region of Santa Catarina state, Brazil. Minerals Engineering 24: $1215-1218$.

187. Warshawsky D, Cody T, Radike M, Reilman R, Schumann B, et al. (1995) Biotransformation of benzo [a] pyrene and other polycyclic aromatic hydrocarbons and heterocyclic analogs by several green algae and other algal species under gold and white light. Chem Biol Interact 97: 131-148.

188. Cerniglia CE, Gibson DT, Van Baalen C (1980) Oxidation of naphthalene by cyanobacteria and microalgae. J Gen Microbiol 116: 495-500.

189. Kang KH, Jang JK, Pham TH, Moon H, Chang IS, et al. (2003) A microbia fuel cell with improved cathode reaction as a low biochemical oxygen demand sensor. Biotechnol Lett 25: 1357-1361.

190. Chang IS, Moon H, Jang JK, Kim BH (2005) Improvement of a microbial fuel cell performance as a BOD sensor using respiratory inhibitors. Biosens Bioelectron 20: 1856-1859.

191. Kumlanghan A, Liu J, Thavarungkul P, Kanatharana P, Mattiasson B (2007) Microbial fuel cell-based biosensor for fast analysis of biodegradable organic matter. Biosens Bioelectron 22: 2939-2944.

192.Zou Y, Pisciotta J, Billmyre RB, Baskakov IV (2009) Photosynthetic microbia fuel cells with positive light response. Biotechnol Bioeng 104: 939-946.

193. Pisciotta JM, Zou Y, Baskakov IV (2011) Role of the photosynthetic electron transfer chain in electrogenic activity of cyanobacteria. Appl Microbiol Biotechnol 91: 377-385

194. Huovinen M, Loikkanen J, Naarala J, Vähäkangas K (2015) Toxicity of diuron in human cancer cells. Toxicol In Vitro 29: 1577-1586.

195. King ST, Sylvander M, Kheperu M, Racz L, Harper WF Jr (2014) Detecting recalcitrant organic chemicals in water with microbial fuel cells and artificial neural networks. Sci Total Environ 497-498: 527-33.

196. Logan BE (2009) Exoelectrogenic bacteria that power microbial fuel cells. Nat Rev Microbiol 7: 375-381.

197. Shantaram A, Beyenal H, Raajan R, Veluchamy A, Lewandowski Z (2005) 
Citation: Pisciotta JM, Dolceamore JJ (2016) Bioelectrochemical and Conventional Bioremediation of Environmental Pollutants. J Microb Biochem Technol 8: 327-343. doi: 10.4172/1948-5948.1000306

Wireless sensors powered by microbial fuel cells. Environ Sci Technol 39: 5037-5042.

198. Roy M, Khara P, Dutta TK (2012) meta-Cleavage of hydroxynaphthoic acids in the degradation of phenanthrene by Sphingobium sp. strain PNB. Microbiology 158: $685-695$

199. Alvarez PJ, IIIman WA (2005) Bioremediation and natural attenuation: Process fundamentals and mathematical models. John Wiley \& Sons.

200. Foght J, April T, Biggar K, Aislabie J (2001) Bioremediation of DDT- contaminated soils: A review. Bioremediation J 5: 225-246

201. Vidali M (2001) Bioremediation. An overview Pure Appl Chem 73: 1163-1172.

202. Cao X, Song HL, Yu CY, Li XN (2015) Simultaneous degradation of toxic refractory organic pesticide and bioelectricity generation using a soil microbial fuel cell. Bioresour Technol 189: 87-93.

203. Wang L, Liu Y, Ma J, Zhao F4 (2016) Rapid degradation of sulphamethoxazole and the further transformation of 3-amino-5-methylisoxazole in a microbial fuel cell. Water Res 88: 322-328. 